\title{
Paula Gamus
}

Katedra Bibliotekoznawstwa i Informacji Naukowej UŁ

\section{Księgozbiór Zaktadu Bibliotekoznawstwa Uniwersytetu Eódzkiego zgromadzony przez Jana Muszkowskiego w latach 1945-1953}

W artykule zaprezentowano świadectwo i losy księgozbioru nazywanego przez osoby związane z łódzką Katedrą Bibliotekoznawstwa „Księgozbiorem Muszkowskiego". Nazewnictwo to jest niebezpodstawne, gdyż profesor Jan Muszkowski, który był założycielem i zarazem pierwszym kierownikiem Zakładu Bibliotekoznawstwa, miał niebagatelny wpływ na charakter powstającej biblioteki. Dowodem na to są relacje naocznych świadków, wpisy do księgi inwentarzowej oraz znaki proweniencyjne widniejące na niektórych egzemplarzach książek. Podstawę niniejszego opracowania stanowią zbiory zgromadzone od początku istnienia kierunku aż do momentu śmierci profesora, czyli od 1945 do 1953 r. Niestety, księga inwentarzowa, która stanowiła tu jedno z dodatkowych źródeł informacji nie zawiera kompletu danych dotyczących sposobu nabycia nowych pozycji, dlatego też zawarte tu informacje dotyczą jedynie części księgozbioru. Ponadto w 1960 r. ze względu na trudne warunki lokalowe $^{1}$, z omawianego tutaj zbioru liczącego ponad 2240 woluminów, ponad 800 przeniesiono do Biblioteki Uniwersyteckiej w Łodzi, w której z kolei z różnych przyczyn pewna jego część została zlikwidowana ${ }^{2}$. Biorąc pod uwagę powyższe, materiał egzemplifikacyjny stanowiły 1343 pozycje, które w chwili obecnej znajdują się w magazynie Biblioteki Katedry Bibliotekoznawstwa i Informacji Naukowej UŁ. Ze względu na charakter niniejszego tekstu szczegółowym

${ }^{1}$ Więcej informacji odnośnie lokalizacji kierunku można znaleźć w artykule: H.Więckowska, Pierwsza w Polsce Katedra Bibliotekoznawstwa. „Przegląd Biblioteczny” 1969, R. 37, z. 2-3, s. 113-134.

2 Informacja pobrana z Archiwum Biblioteki Uniwersyteckiej. 
oględzinom poddane zostały 233 pozycje, które nosiły różnego rodzaju znaki proweniencyjne, co w połączeniu z informacjami z inwentarza dało możliwie rzetelny wynik opracowania.

Historia księgozbioru Biblioteki Katedry Bibliotekoznawstwa i Informacji Naukowej ściśle wiąże się z dziejami samej Katedry, która przez szereg lat musiała walczyć o swoje miejsce na mapie Łodzi, co miało duży wpływ na bibliotekę w pierwszych latach jej istnienia, jak i później.

Pierwotnie Zakład Bibliotekoznawstwa mieścił się w mieszkaniu prof. Jana Muszkowskiego przy ulicy Uniwersyteckiej 3. Profesor dysponując trzema pokojami udostępnił jeden z nich do celów dydaktycznych. W tym jednym pomieszczeniu z czasem, za sprawą profesora, zaczęła powstawać biblioteka, która w tamtym okresie stanowiła księgozbiór „podręczny” ${ }^{2}$. Dary, trafiające do biblioteki pochodziły nie tylko od samego Jana Muszkowskiego, choć w ich pozyskiwaniu odegrał on znaczącą rolę, gdyż dzięki swojej ogromnej wiedzy z zakresu bibliotekoznawstwa oraz funkcjom, które sprawował, darzono go w środowisku naukowym dużym poważaniem, co w sposób znaczący ułatwiło pozyskiwanie nowych publikacji do biblioteki ${ }^{4}$.

Profil gromadzonego księgozbioru w początkowych latach istnienia kierunku odpowiadał potrzebom zadań realizowanych na uczelni. Dlatego też, w jego skład weszły publikacje z zakresu bibliotekarstwa, bibliografii, bibliofilstwa, historii książki, księgarstwa, czytelnictwa i informacji naukowej. Ponadto w bibliotece można było znaleźć pozycje z zakresu literatury, historii czy socjologii, później jednak pozycje te zostały przekazane w darze Bibliotece Uniwersyteckiej w Łodzi.

Wśród księgozbioru zgromadzonego przez Jana Muszkowskiego przeważały pozycje polsko- i niemieckojęzyczne. Profesor biegle posługiwał się kilkoma językami, więc nie zabrakło również publikacji napisanych w języku angielskim, francuskim, rosyjskim a nawet szwedzkim. Były to jednak pojedyncze egzemplarze. Zaskakuje zatem fakt, iż w wyselekcjonowanym materiale daje się zaobserwować przewagę pozycji obcojęzycznych; jest ich 62\%. Publikacje w języku polskim stanowią $38 \%$ zbiorów, zawierających znaki proweniencyjne.

${ }^{3}$ Z relacji Haliny Werno, która była opiekunem księgozbioru od 1956 do 1960 r. wynika, iż w czasie prowadzonych przez profesora zajęć niejednokrotnie udawał się on do swoich prywatnych pokoi po książki, które były potrzebne słuchaczom do zrozumienia i pogłębienia omawianej problematyki. Pozycje, które profesor udostępniał na wykładach zwykle zostawały już w Katedrze. Ze względu na znikomą ilość źródeł, które opisywałyby okoliczności zorganizowania Biblioteki można podejrzewać, że właśnie w ten sposób, podczas pierwszych zajęć, zaczęła ona powstawać.

4 Następczyni profesora Helena Więckowska w swoim artykule w „Przeglądzie Bibliotecznym” z 1969 r. podkreśliła, iż zgromadzony w Katedrze przez profesora księgozbiór był starannie dobranym materiałem bibliologicznym do wykładów i ćwiczeń. 
Tabela 1. Liczba publikacji w języku polskim i obcym

\begin{tabular}{|l|r|r|}
\hline Rodzaj publikacji & Liczba egz. & $\%$ \\
\hline Obcojęzyczne & 145 & 62 \\
\hline Polskojęzyczne & 88 & 38 \\
\hline Razem & 233 & 100 \\
\hline
\end{tabular}

Źródło: Opracowanie własne.

W zgromadzonym materiale większość publikacji, bo aż $81 \%$ pochodzi z XX wieku, natomiast zdecydowaną jego mniejszość stanowią teksty wydane w XIX wieku.

\section{Tabela 2. Rok wydania badanych publikacji}

\begin{tabular}{|l|r|r|}
\hline Rok wydania & Liczba egz. & $\%$ \\
\hline $1817-1900$ & 27 & 12 \\
\hline $1901-1952$ & 189 & 81 \\
\hline Brak daty wydania & 17 & 7 \\
\hline Razem & 233 & 100 \\
\hline
\end{tabular}

Źródło: Opracowanie własne.

Wydzielone 233 pozycje z całości księgozbioru, to w zasadzie dary od różnego rodzaju instytucji nauki, wydawców i osób prywatnych. Analizując informacje z inwentarza oraz zapiski własnościowe znalezione na poszczególnych egzemplarzach książek, można wskazać 222 pozycje, które zostały przekazane przez profesora w darze dla biblioteki. Część z nich została przeniesiona do BUŁ. W skład księgozbioru, wchodziło także ponad 300 pozycji, przekazanych przez Państwowy Instytut Książki, a precyzyjniej, przez zarządzającego tą instytucją w latach 1946-1949, Adama Łysakowskiego, bliskiego znajomego profesora. Ponadto, Adam Łysakowski w latach 1946-1948 sprawował też funkcję dyrektora Biblioteki Uniwersyteckiej w Łodzi. W tamtym okresie istniał silny związek między tymi dwiema bibliotekami, które wzajemnie się uzupełniały. Ta zależność zaowocowała ponad setką książek przekazanych bibliotece zakładowej w darze bądź w drodze wymiany (132 pozycje). Niestety, znaczącą część tego zbioru wycofano do BUŁ bądź ubytkowano, dlatego nie da się ustalić, czy pozycje te nosiły jakieś osobiste oznaczenia poza tą niewielką częścią, która się zachowała.

Wśród książek przekazanych Zakładowi przez inne instytucje znajdują się pozycje z bibliotek akademickich, m.in.: z Warszawy, Krakowa, Poznania czy 
Wilna. Oprócz publikacji z książnic uczelniach występują tu także liczne pozycje z bibliotek publicznych: Łodzi, Radomia, Szczecina oraz bibliotek szkolnych z Wrocławia. Poza tym, są też pojedyncze egzemplarze z takich książnic jak: Biblioteka Czartoryskich, Biblioteka Zielińskich - Towarzystwa Naukowego w Płocku i Izraelickiej Biblioteki Gminnej. Dzięki licznym kontaktom Jana Muszkowskiego z zagranicznymi ośrodkami, m.in. ze Szwecją, do księgozbioru trafily w sumie 22 pozycje ofiarowane przez Bibliotekę w Uppsali, co stanowi interesujący ślad kontaktów profesora z zagranicznymi ośrodkami naukowymi.

Niewielką część publikacji podarowanych bibliotece, stanowi darowizna od osób prywatnych. Zapisy z inwentarza wskazują, że takich pozycji było kilkadziesiąt. Niestety, czas nie wpłynął korzystnie na jakość ich zachowania. Część woluminów nosi ślady bytności pieczęci, których jednak dziś nie da się odczytać, niektóre prawdopodobnie zniknęły całkowicie. W tym przypadku najciekawszym materiałem badawczym są pozycje z dedykacjami dla profesora. W gronie darczyńców, którzy dołączyli do publikacji swój wpis można znaleźć m.in. dedykacje: Józefa Grycza, Adama Łysakowskiego, Heleny Radlińskiej, Krystyny Remerowej oraz kilku innych. Zamieszczane wpisy zwykle mają charakter grzecznościowy, jednak niektóre pozwalają określić relacje między nadawcą i odbiorcą tych krótkich wiadomości. Kilka zapisów niesie z sobą bardzo pozytywny przekaz, mianowicie:

- „Prof. J. Muszkowskiemu na pamiątkę dawnych miłych prac wspólnych”. H. Radlińska. 25.III. 47

- „Mojemu Kochanemu Profesorowi Janowi Muszkowskiemu”. Julia Mellerowa

- „Na pamiątkę bezkrwawej grabieży”. Z[uzanna] Rabska. Rok 1940 16.IX

- „Wielmożnemu Panu Dr. Janowi Muszkowskiemu pierwszemu profesorowi bibliologii z wyrazami prawdziwego poważania i przyjaźni składa autor".

[Adam Łysakowski]. Łódź 21 sierpnia 1946

- „Panu Janowi Muszkowskiemu naszemu bibliotekarskiemu profesorowi w dowód wielkiego szacunku składa”.

J[ózef] Grycz. 21.IV.1950

- „Panu Prof. Muszkowskiemu. W półtora roku po wydaniu w końcu dziś dostałem”.

K[sawery] Świerkowski 8.I.525

\footnotetext{
5 Źródło: patrz załącznik nr 1.
} 
Łącznie, w Bibliotece KBIN znajduje się 28 pozycji z dedykacjami, w tym aż 17 dla profesora. Pozostałe są opatrzone wpisem dla biblioteki zakładowej oraz innych osób związanych z książką, np.: Stefana Rygla.

Niemalże równie cenne pozycje, jak te z dedykacjami, to 6 tytułów z ekslibrisami. Właścicielami druków zaopatrzonych w ekslibrisy były następujące osoby:

- Michał Brensztejn ${ }^{6}$,

- Zygmunt Klemensiewicz ${ }^{7}$,

- Kazimierz Reychman (dwie pozycje) $)^{8}$,

- Biblioteka Uniwersytecka w Poznaniu

oraz Biblioteka Schloos Plathe Pommern.

Prawdopodobnie można byłoby powiedzieć o losach tych książek nieco więcej gdyby w inwentarzu istniały stosowne adnotacje o sposobie ich nabycia, jednak tylko w dwóch przypadkach podano źródło ich pozyskania: książka oznaczona ekslibrisem biblioteki Schloos Plathe Pommern jest darem od Państwowego Instytutu Książki, natomiast publikacja należąca do Kazimierza Reychmana została przez bibliotekę zakupiona.

Znaczącą część zgromadzonego materiału stanowią teksty z pieczęciami. Prym wiodą publikacje podarowane przez BUŁ (46 pozycji) i PIK (29 pozycji). Tabela 3 prezentuje też pozostałe instytucje, z których pochodzi więcej niż jedna pozycja ze zbioru.

Dość liczne są również stemple z nazwiskami właścicieli danej pozycji. Obecnie z całą pewnością udało się wyselekcjonować 20 takich stempli, jednak można przypuszczać, że było ich więcej, ale z biegiem lat część przystawionych pieczęci wyblakła na tyle, że trudno jest odgadnąć kto był ich właścicielem. Wśród 20 odnalezionych przykładów aż 7 pozycji należało do Witolda

${ }^{6}$ Michał Brensztejn przez wiele lat był członkiem dwóch stowarzyszeń: Towarzystwa Przyjaciół Nauk i Towarzystwa Bibliofilów Polskich w Wilnie. Jego pasją było gromadzenie książek i ekslibrisów, które później przekazywał innym instytucjom. Pracował na stanowisku bibliotekarza w Uniwersyteckiej Bibliotece Publicznej w Wilnie. Źródło: Stownik Pracowników Ksiązki Polskiej. Pod red. I. Treichel. Warszawa 1972, s. 78-79

${ }^{7}$ Zygmunt Klemensiewicz kolekcjonował ekslibrisy, posiadał ich ponad 7 tys. Był członkiem Towarzystwa Miłośników Książki w Krakowie. Zbiory po jego śmierci trafiły do Zakładu Narodowego im. Ossolińskich. Źródło: Encyklopedia Wiedzy o Książce. Pod red. A. Birkenmajera. Wrocław 1971, s. 1778-1779.

${ }^{8}$ Kazimierz Reychman był właścicielem biblioteki poświęconej ekslibrisologii, historii bibliofilstwa i bibliotekarstwa. Zgromadził zbiór ekslibrisów, który uważany był za jeden z najważniejszych w kraju. Był współzałożycielem Towarzystwa Miłośników Ekslibrisu oraz członkiem Towarzystwa Bibliofilów Polskich w Warszawie. Źródło: Polski Stownik Biograficzny. Pod red. E. Rostworowskiego. Wrocław 1988-1989, T. 31, s. 213. 
Tabela 3. Liczba publikacji z pieczęciami różnych instytucji

\begin{tabular}{|l|c|}
\hline BUt & 46 \\
\hline PIK & 29 \\
\hline Aus der Stadbücherei Stettin & 14 \\
\hline Stadtbücherei Litzmannstadt & 9 \\
\hline $\begin{array}{l}\text { Handbücherei Staatl. Beratungstelle fur das } \\
\text { Volksbüchereiwesender Provinz Oberschlesien... }\end{array}$ \\
\hline Stettiner Büchereischule & 8 \\
\hline Die Deutsche Arbeitsfront & 7 \\
\hline Stadt-Bibliothek Konigsberg & 4 \\
\hline Stadtbibliothek Stettin & 4 \\
\hline Bibliotehek d. Kammer f.Arbeiter a. Angestellte in Wien & 3 \\
\hline Komitet Zbiórki na potrzeby Dziecka i Młodzieży & 3 \\
na Ziemiach Odzyskanych w Londynie & 3 \\
\hline Społem Biblioteka & 3 \\
\hline Stadtbibliothek Aonigsberg & 3 \\
\hline Wolna Wszechnica Polska & 3 \\
\hline Zentralarchiv DHV & 2 \\
\hline Miejska Biblioteka Publiczna w Radomiu & 2 \\
\hline Biblioteka Miejska m. Radom & 2 \\
\hline Stadt. Volfsbüchereien Stettin & 2 \\
\hline Stadtbücherei. Hindenburg & \\
\hline Magistrat der Stadt Konigeberg Pr.Stadtbibliothek & 2 \\
\hline
\end{tabular}

Źródło: Opracowanie własne.

Dunina-Wilczyńskiego, 3 do prof. Muszkowskiego, dwie pozycje pochodzą ze zbiorów Kazimierza Szłapki i również dwie z biblioteczki Zygmunta Karpowicza. Resztę stanowią przykłady pojedyncze. Na podstawie pieczęci Jana Muszkowskiego można przypuszczać, że te 3 publikacje profesor przywiózł do Łodzi z Warszawy, gdyż poza imieniem i nazwiskiem, pieczątka zawiera również informację o miejscu zamieszkania jej właściciela, w tym przypadku była to Warszawa.

Odnalezione znaki proweniencyjne pozwalają stwierdzić, że część książek, zanim dotarła do obecnego miejsca pobytu, przebyła długą drogę. Przykładem tego są chociażby pozycje z ekslibrisami wskazującymi na takie miejsca, jak: Szczecin, Kraków czy Ameryka Południowa. Często też książki miały więcej 
niż jednego właściciela (17 pozycji). Ponadto dzięki zachowanym proweniencjom zostały uchwycone związki profesora z Biblioteką w Uppsali oraz potwierdziły się jego liczne znajomości z ludźmi nauki oraz instytucjami blisko związanymi z książką. Ciekawą grupę zaprezentowanych tu znaków proweniencyjnych, niosących niezwykle pozytywny przekaz, stanowią dedykacje dla profesora. Tworzą one świadectwo niezwykłego poszanowania, jakim darzyli go autorzy tych notatek oraz w pewnym stopniu obrazują one niezwykły charakter profesora.

\section{Abstract \\ The books in the Chair of Library Science Library at University of Lodz collected by Jan Muszkowski in the years 1945-1953}

The article presents the bibliographic compilation concerning the books collected by prof. Jan Muszkowski in the Chair of Library Science Library at University of Lodz. The author analysed the dedications, stamps and other proprietary marks and presented the table of prof. Jan Muszkowski's heritage currently stored in the Chair of Librarianship and Information Science. 


\section{Załącznik nr 1. Wykaz publikacji, w których znaleziono znaki prowenien- cyjne $z$ podziałem na typ znaku}

Dane do tabeli sporządzone zostały z autopsji. Informacje uszeregowano pod względem kolejności sygnatury księgozbioru z Biblioteki Katedry Bibliotekoznawstwa UŁ. Wolne miejsca w tabeli to dane, których nie udało się ustalić. Tam gdzie znaki własnościowe były widoczne, ale nieczytelne zostało to zaznaczone.

\begin{tabular}{|c|c|c|c|c|c|c|c|}
\hline 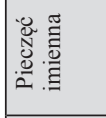 & & & & & & 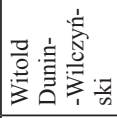 & \\
\hline $\begin{array}{l}\frac{\pi}{0} \\
\frac{\pi}{\pi} \\
\frac{\pi}{0} \\
0\end{array}$ & & & & 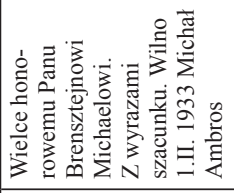 & & & \\
\hline 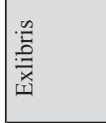 & & & & 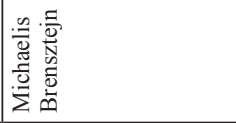 & & & \\
\hline 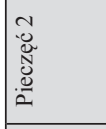 & & 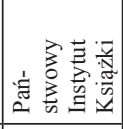 & 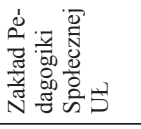 & & & & \\
\hline 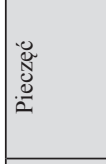 & 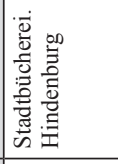 & 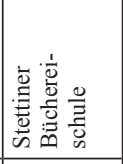 & 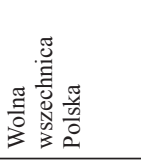 & & 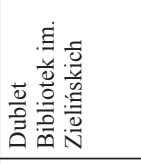 & & 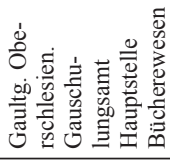 \\
\hline 咅 & \begin{tabular}{|l|}
\multirow{0}{*}{} \\
ते
\end{tabular} & \begin{tabular}{|l|}
\multirow{0}{0}{} \\
ปิ
\end{tabular} & 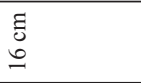 & \begin{tabular}{|l}
5 \\
$\vdots$ \\
$\varrho$
\end{tabular} & $\begin{array}{l}\text { ह } \\
2 \\
2\end{array}$ & \begin{tabular}{|l}
5 \\
5 \\
2
\end{tabular} & $\begin{array}{l}\dot{m} \\
\ddot{\lambda}\end{array}$ \\
\hline 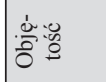 & $\begin{array}{l}\dot{\infty} \\
\dot{\infty}\end{array}$ & $\begin{array}{l}\dot{\infty} \\
\infty \\
\dot{n}\end{array}$ & $\frac{\dot{m}}{\vec{\infty}}$ & $\dot{0}$ & $\underset{\mathbb{N}}{\bar{N}}$ & $\frac{\dot{m}}{m}$ & $\begin{array}{l}\dot{\infty} \\
\text { ते } \\
\text { הे }\end{array}$ \\
\hline 关 & & 志 & $\stackrel{\infty}{\infty}$ & $\approx$ & बे & ๙ิ & $\stackrel{2}{2}$ \\
\hline 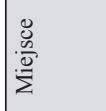 & & $\begin{array}{l}\text { 吾 } \\
\text { 离 }\end{array}$ & 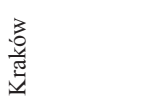 & 章 & 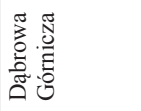 & 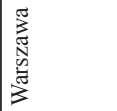 & 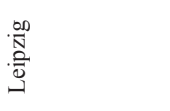 \\
\hline$\stackrel{\text { 节 }}{*}$ & 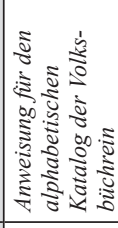 & 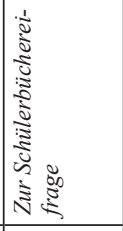 & 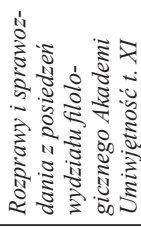 & 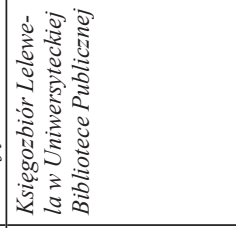 & 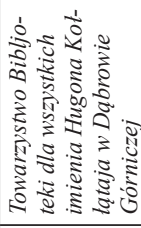 & 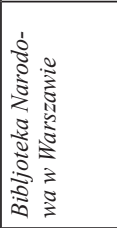 & 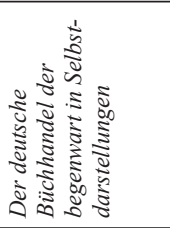 \\
\hline 苍 & & & & 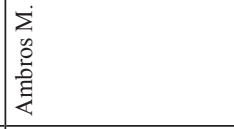 & & 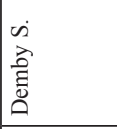 & $\begin{array}{l}0 \\
N \\
N \\
\\
\end{array}$ \\
\hline 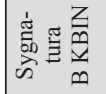 & $=$ & ஓి & 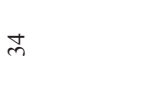 & in & 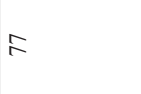 & $\infty$ & $\bar{\sigma}$ \\
\hline
\end{tabular}




\begin{tabular}{|c|c|c|c|c|c|c|c|c|c|c|c|}
\hline 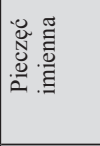 & 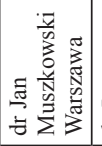 & 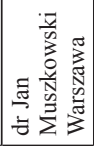 & & & & & & & 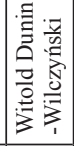 & & \\
\hline 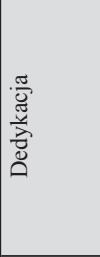 & & & & & 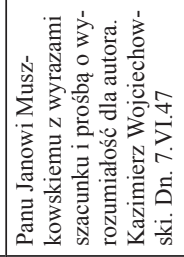 & 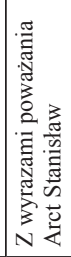 & & & & 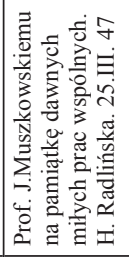 & \\
\hline 䰹 & & & & & & & & & & & \\
\hline 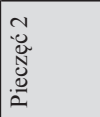 & & & & & & & & & & & \\
\hline 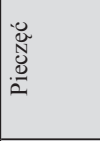 & & & 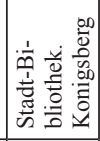 & 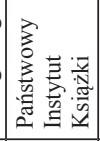 & & & 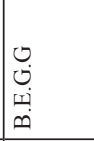 & 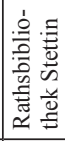 & & & 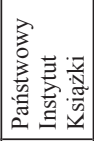 \\
\hline 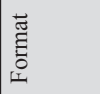 & 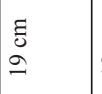 & $\begin{array}{l}\tilde{\Xi} \\
\stackrel{7}{2}\end{array}$ & 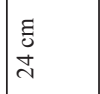 & ह & ह & ह & $\begin{array}{l}\Xi \\
\tilde{\Xi} \\
\text { ป }\end{array}$ & $\begin{array}{c}\tilde{\Xi} \\
\bar{\sim}\end{array}$ & $\frac{\Xi}{\bar{\nu}}$ & 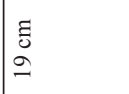 & 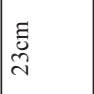 \\
\hline $\mid$ & $\begin{array}{l}\dot{\infty} \\
\Xi \\
\dot{\Xi}\end{array}$ & $\begin{array}{l}\dot{\infty} \\
\stackrel{D}{D} \\
\infty \\
i n\end{array}$ & $\begin{array}{l}\dot{m} \\
\stackrel{a}{a} \\
\dot{y} \\
\dot{n}\end{array}$ & $\begin{array}{l}\dot{s} \\
\frac{\dot{n}}{n} \\
\dot{q}\end{array}$ & 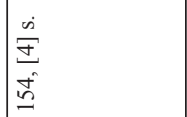 & $\begin{array}{l}\dot{m} \\
\dot{I}\end{array}$ & $\begin{array}{l}\dot{\infty} \\
\infty \\
\tilde{\omega}\end{array}$ & $\begin{array}{l}\dot{m} \\
\stackrel{\dot{a}}{a} \\
\dot{\infty} \\
\dot{m}\end{array}$ & $\begin{array}{l}\dot{\infty} \\
\infty \\
=\end{array}$ & 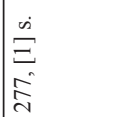 & $\begin{array}{l}\dot{\infty} \\
\dot{\infty} \\
\infty\end{array}$ \\
\hline 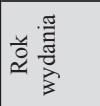 & $\stackrel{ \pm}{2}$ & $\tilde{\sigma}$ & 垔 & $\stackrel{2}{2}$ & 乎 & $\stackrel{0}{2}$ & 㦘 & ఏ & $\stackrel{\infty}{\sigma}$ & 告 & $\stackrel{\varrho}{\varrho}$ \\
\hline 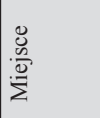 & 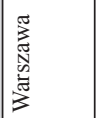 & 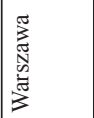 & 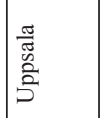 & 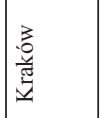 & 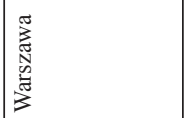 & 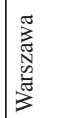 & 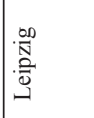 & 吾 & 言 & 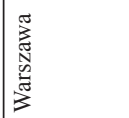 & 离 \\
\hline 胥 & 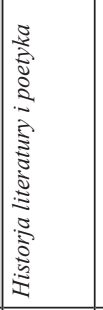 & 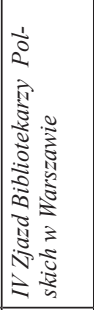 & 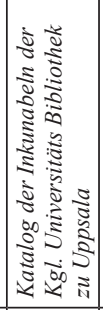 & 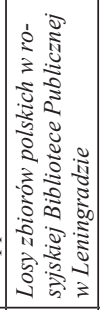 & 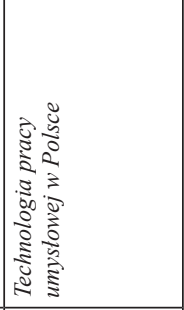 & 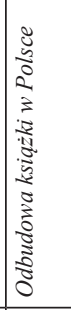 & 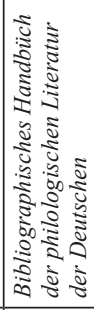 & 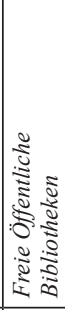 & 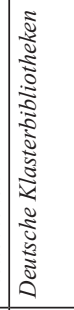 & 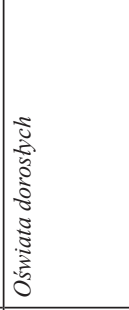 & 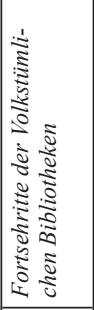 \\
\hline 章 & 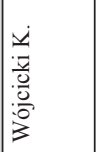 & & 容 & 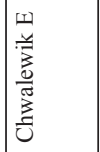 & 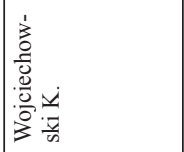 & \begin{tabular}{|l}
$\dot{2}$ \\
$\dot{y}$ \\
$\dot{z}$
\end{tabular} & 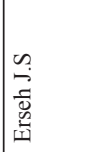 & 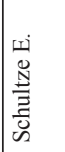 & 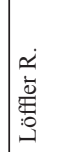 & 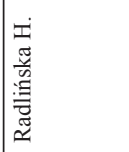 & 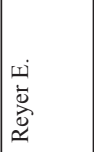 \\
\hline 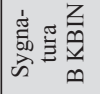 & $\Xi$ & $\stackrel{m}{=}$ & $\stackrel{\Xi}{\beth}$ & $\stackrel{n}{\Omega}$ & $\stackrel{n}{n}$ & $\stackrel{8}{\stackrel{8}{0}}$ & $\stackrel{2}{6}$ & $\stackrel{6}{\sigma}$ & $\Xi$ & $\infty$ & $\frac{\sim}{\sim}$ \\
\hline
\end{tabular}




\begin{tabular}{|c|c|c|c|c|c|c|c|c|c|c|c|}
\hline 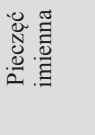 & & 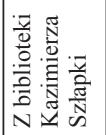 & & & & & & & & & \\
\hline 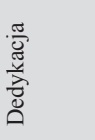 & & & & & & & & & & & \\
\hline 鵕 & & & & & & & & & & & \\
\hline 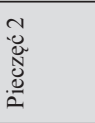 & & & & & & & 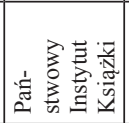 & & & & \\
\hline 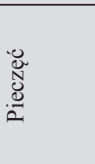 & & 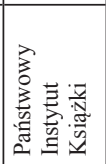 & & 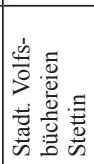 & 竞: & 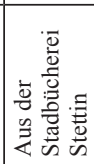 & 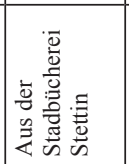 & 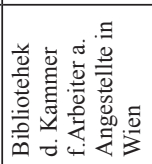 & 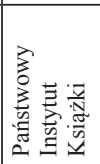 & 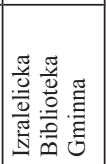 & 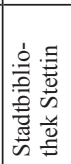 \\
\hline 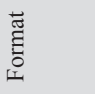 & $\begin{array}{l}\tilde{0} \\
\stackrel{\sim}{~}\end{array}$ & $\begin{array}{l}\tilde{0} \\
\text { ते }\end{array}$ & हี & $\begin{array}{l}\tilde{0} \\
\tilde{\lambda}\end{array}$ & $\begin{array}{l}\tilde{\text { J }} \\
\text { ป }\end{array}$ & $\frac{\tilde{\sigma}}{\bar{\sim}}$ & 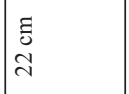 & $\begin{array}{l}\tilde{0} \\
\tilde{\lambda}\end{array}$ & $\begin{array}{l}\tilde{\Xi} \\
\stackrel{\sim}{+}\end{array}$ & ह & $\begin{array}{l}\tilde{\partial} \\
\text { ป }\end{array}$ \\
\hline 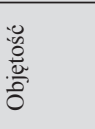 & $\begin{array}{l}\dot{x} \\
\tilde{\alpha}\end{array}$ & $\begin{array}{l}\dot{m} \\
\Xi \\
\\
\tilde{n} \\
n\end{array}$ & $\begin{array}{l}\dot{m} \\
\vec{d} \\
\dot{a} \\
\dot{a}\end{array}$ & $\frac{\dot{m}}{\infty}$ & $\dot{m}$ & $\dot{m}$ & $\begin{array}{l}\dot{m} \\
\dot{\sim}\end{array}$ & $\begin{array}{l}\dot{n} \\
\infty\end{array}$ & $\begin{array}{l}\dot{\infty} \\
\dot{0} \\
0\end{array}$ & $\begin{array}{l}\dot{\infty} \\
\frac{n}{n} \\
\hat{n} \\
=\end{array}$ & $\begin{array}{l}\dot{n} \\
2 \\
\varrho \\
0\end{array}$ \\
\hline 蓆 & $\frac{0}{2}$ & $\tilde{\sigma}$ & $\stackrel{\infty}{\Omega}$ & $\hat{\sigma}$ & 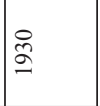 & $\frac{ \pm}{2}$ & $\underset{\Xi}{\stackrel{J}{\Xi}}$ & $\begin{array}{l}\infty \\
\infty \\
\infty\end{array}$ & 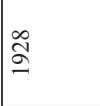 & $\stackrel{\infty}{\Omega}$ & $\frac{\partial}{2}$ \\
\hline 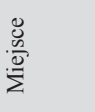 & 寻 & 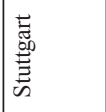 & 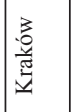 & 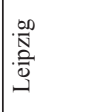 & 声 & 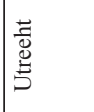 & 递 & 竞 & 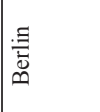 & \begin{tabular}{|l}
3 \\
0 \\
3 \\
3 \\
3
\end{tabular} & 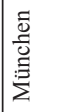 \\
\hline 胥 & 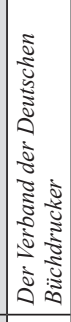 & 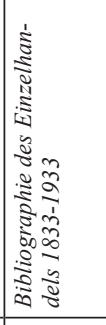 & 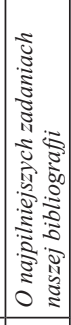 & 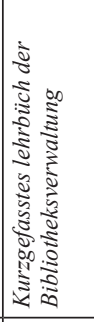 & 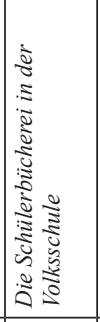 & 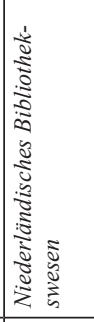 & 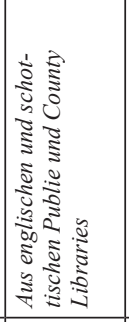 & 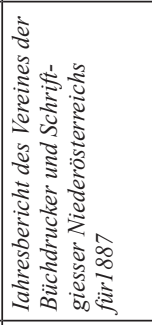 & 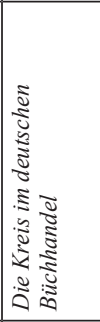 & 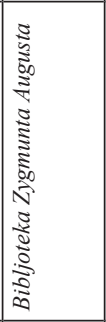 & 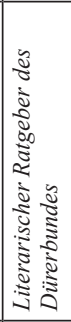 \\
\hline 竞 & 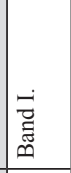 & & 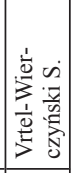 & 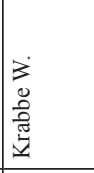 & 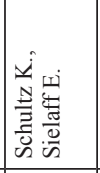 & & 焉 & & 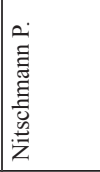 & 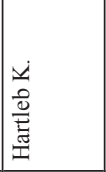 & 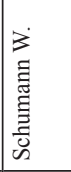 \\
\hline 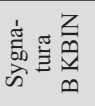 & $\widetilde{\lambda}$ & $\underset{\sim}{\mathbb{N}}$ & $\stackrel{\infty}{\sim}$ & $\overrightarrow{\tilde{\sim}}$ & I & 竎 & $\underset{\sim}{\stackrel{\infty}{\sim}}$ & ڤn & $\hat{\sim}$ & i & $\vec{i}$ \\
\hline
\end{tabular}




\begin{tabular}{|c|c|c|c|c|c|c|c|c|c|c|c|}
\hline 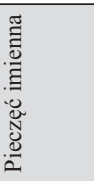 & & & & & & 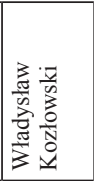 & & & & & 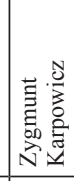 \\
\hline 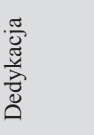 & & & & & & & & & & & \\
\hline$\frac{n}{\frac{0}{x}}$ & & & & & & & & & & & \\
\hline 苋 & & & & & & & & & & & \\
\hline 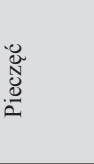 & 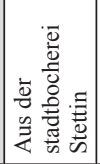 & 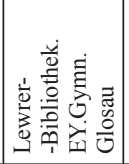 & 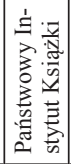 & 峁 & 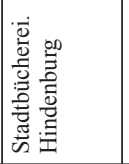 & & 蜶 & 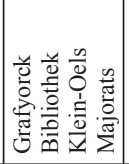 & 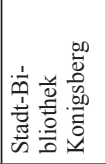 & 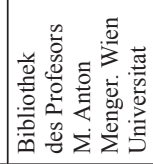 & $\sum_{\infty}$ \\
\hline 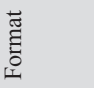 & 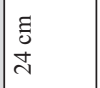 & 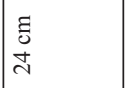 & हี & $\begin{array}{l}\Xi \\
\vdots \\
2\end{array}$ & 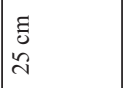 & $\begin{array}{l}\tilde{E} \\
0 \\
0 \\
-\end{array}$ & $\begin{array}{l}\Xi \\
0 \\
2\end{array}$ & 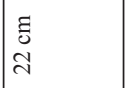 & 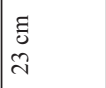 & $\begin{array}{l}\text { ह } \\
\curvearrowright \\
\curvearrowright\end{array}$ & ह \\
\hline : & $\begin{array}{l}\dot{n} \\
\text { in } \\
\text { In }\end{array}$ & $\stackrel{\dot{m}}{=}$ & $\dot{m}$ & $\begin{array}{l}\dot{w} \\
\frac{\dot{a}}{d} \\
\dot{w} \\
\infty \\
m\end{array}$ & $\stackrel{\dot{m}}{\stackrel{\sim}{N}}$ & 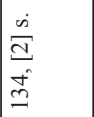 & 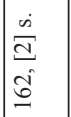 & $\begin{array}{l}\dot{m} \\
\stackrel{2}{\varrho}\end{array}$ & $\begin{array}{l}\dot{m} \\
\tilde{U} \\
\tilde{\sigma}\end{array}$ & $\begin{array}{l}\dot{m} \\
\infty \\
\stackrel{N}{ }\end{array}$ & $\begin{array}{l}\dot{m} \\
\stackrel{\vec{d}}{\infty} \\
\dot{\sim} \\
\sim\end{array}$ \\
\hline 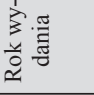 & $\stackrel{\circ}{\varrho}$ & 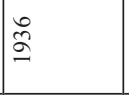 & $\stackrel{\infty}{\mathscr{\Omega}}$ & $\widehat{\widehat{\sigma}}$ & I & ळ & $\frac{n}{2}$ & \begin{tabular}{l}
$n$ \\
\hdashline \\
$\infty$
\end{tabular} & 웅 & $\stackrel{2}{\varrho}$ & $\stackrel{\infty}{\stackrel{\infty}{\Omega}}$ \\
\hline$\frac{.}{\mathscr{W}}$ & 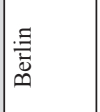 & & \begin{tabular}{|l}
3 \\
0 \\
0 \\
3 \\
3
\end{tabular} & 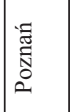 & 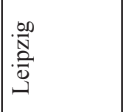 & 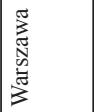 & 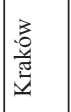 & $\stackrel{\check{\Xi}}{\mathrm{\Xi}}$ & 多 & 营 & 高 \\
\hline 蒂 & 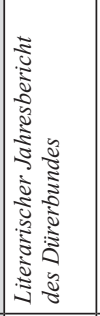 & 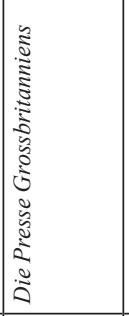 & 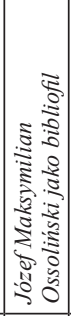 & 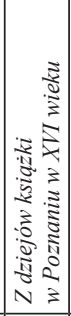 & 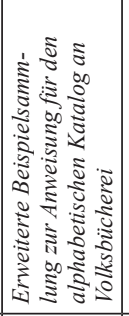 & 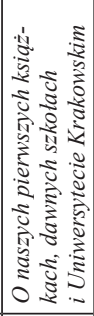 & 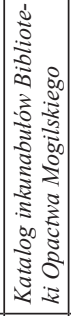 & 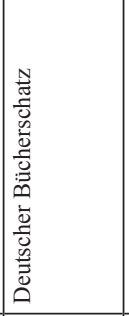 & 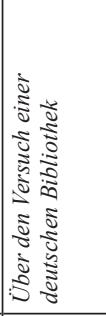 & 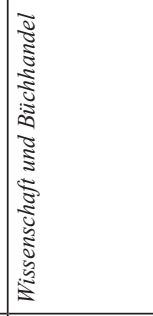 & 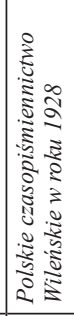 \\
\hline 苍 & & 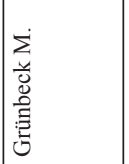 & 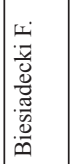 & 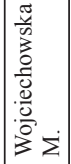 & 这 & $\begin{array}{l}\dot{<} \\
\tilde{n} \\
\tilde{W} \\
0 \\
0\end{array}$ & 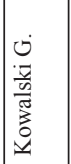 & & 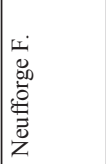 & 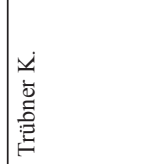 & 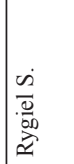 \\
\hline 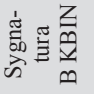 & స్ & 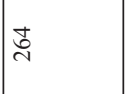 & 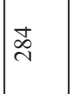 & 占 & 鿖 & 客 & ì & $\stackrel{n}{m}$ & 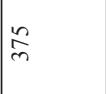 & 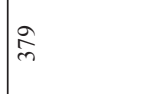 & $\vec{\infty}$ \\
\hline
\end{tabular}




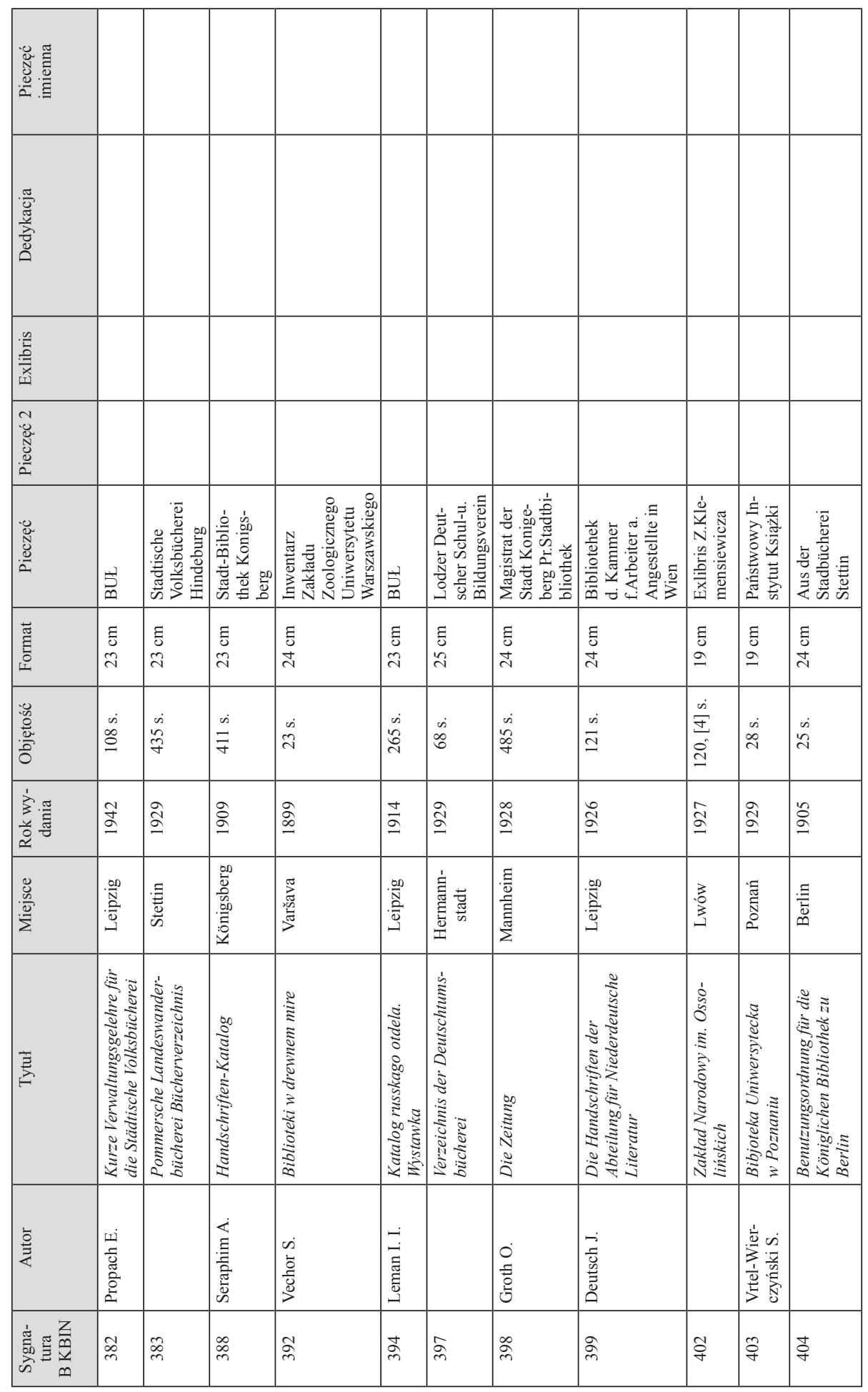




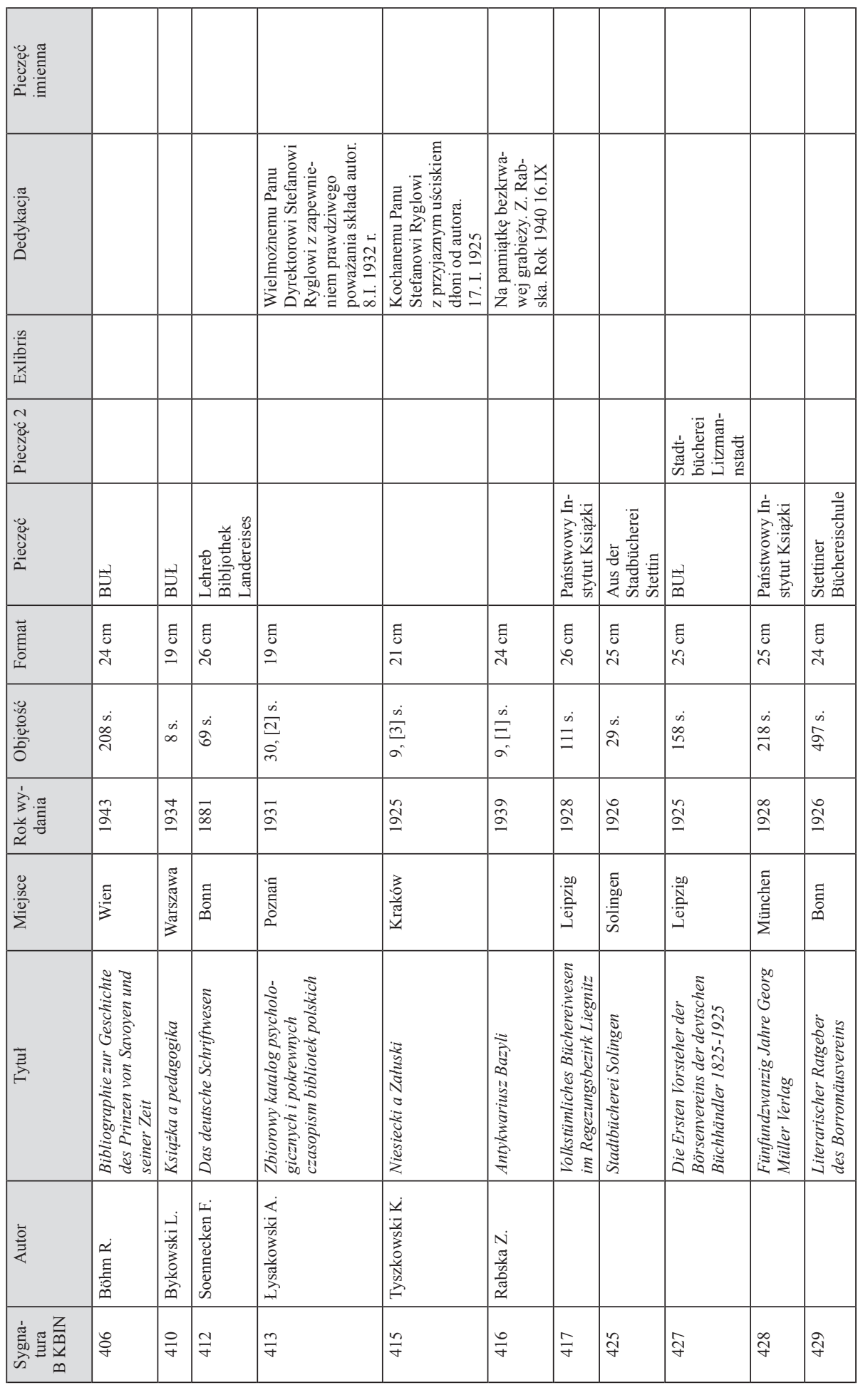




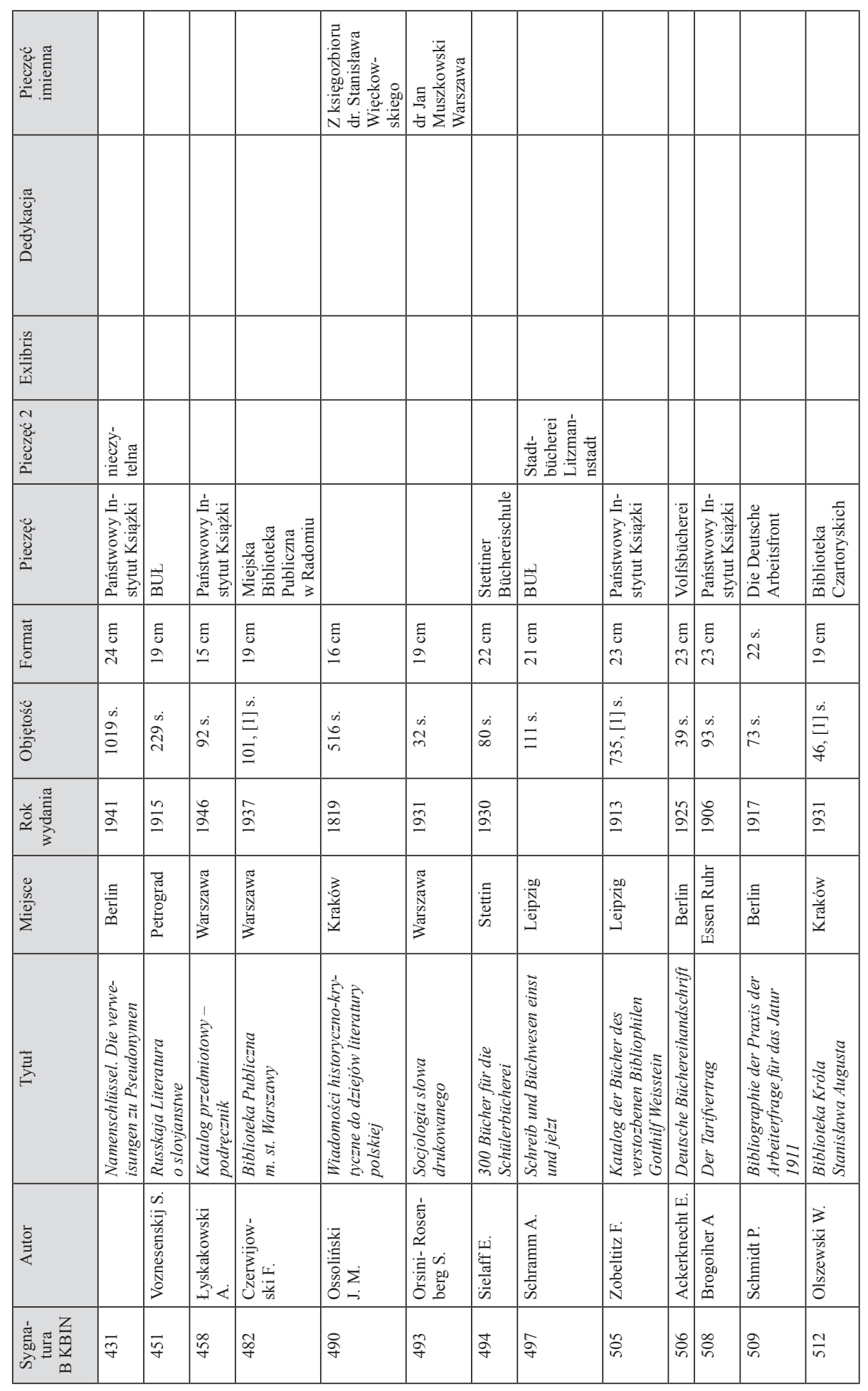




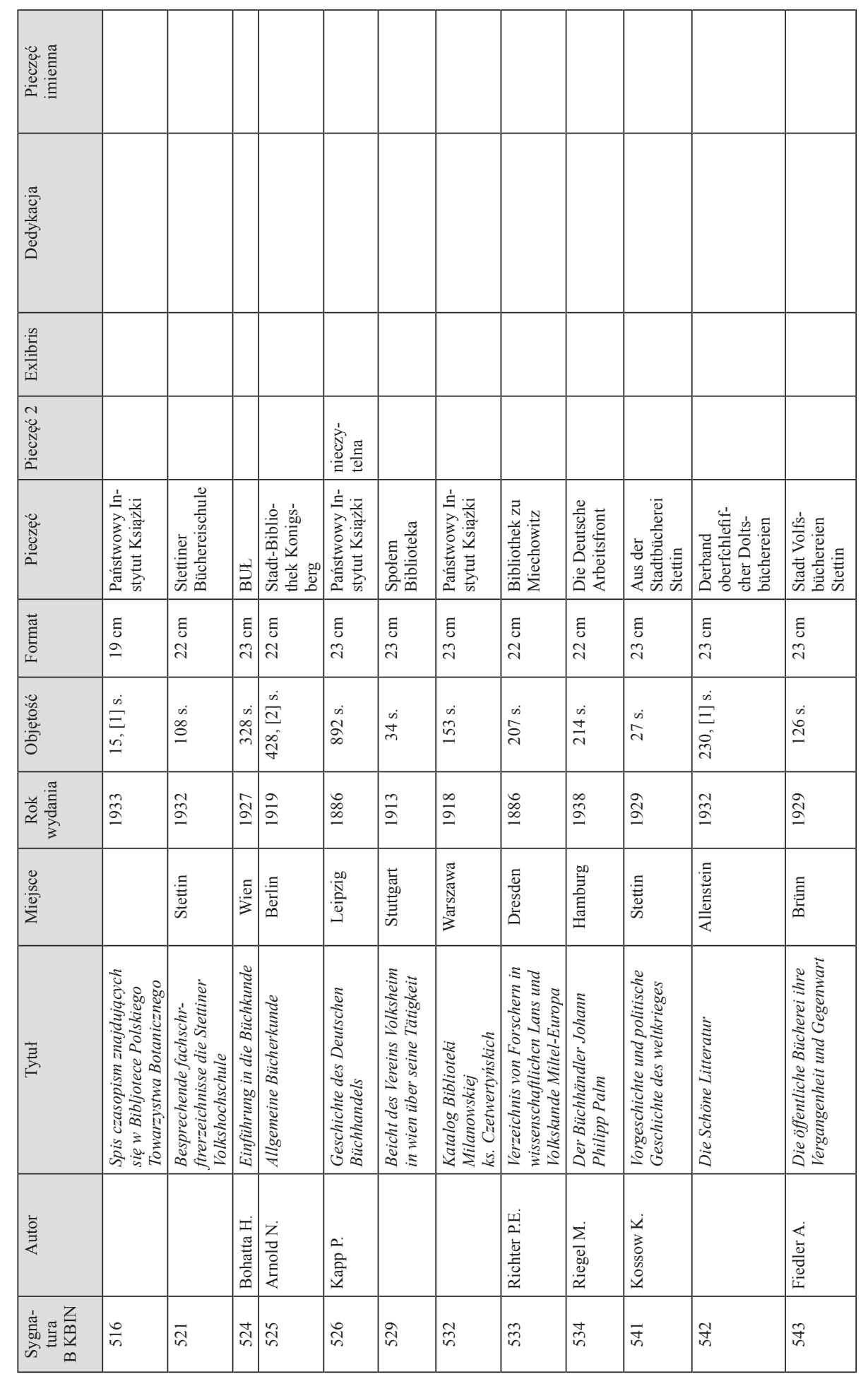




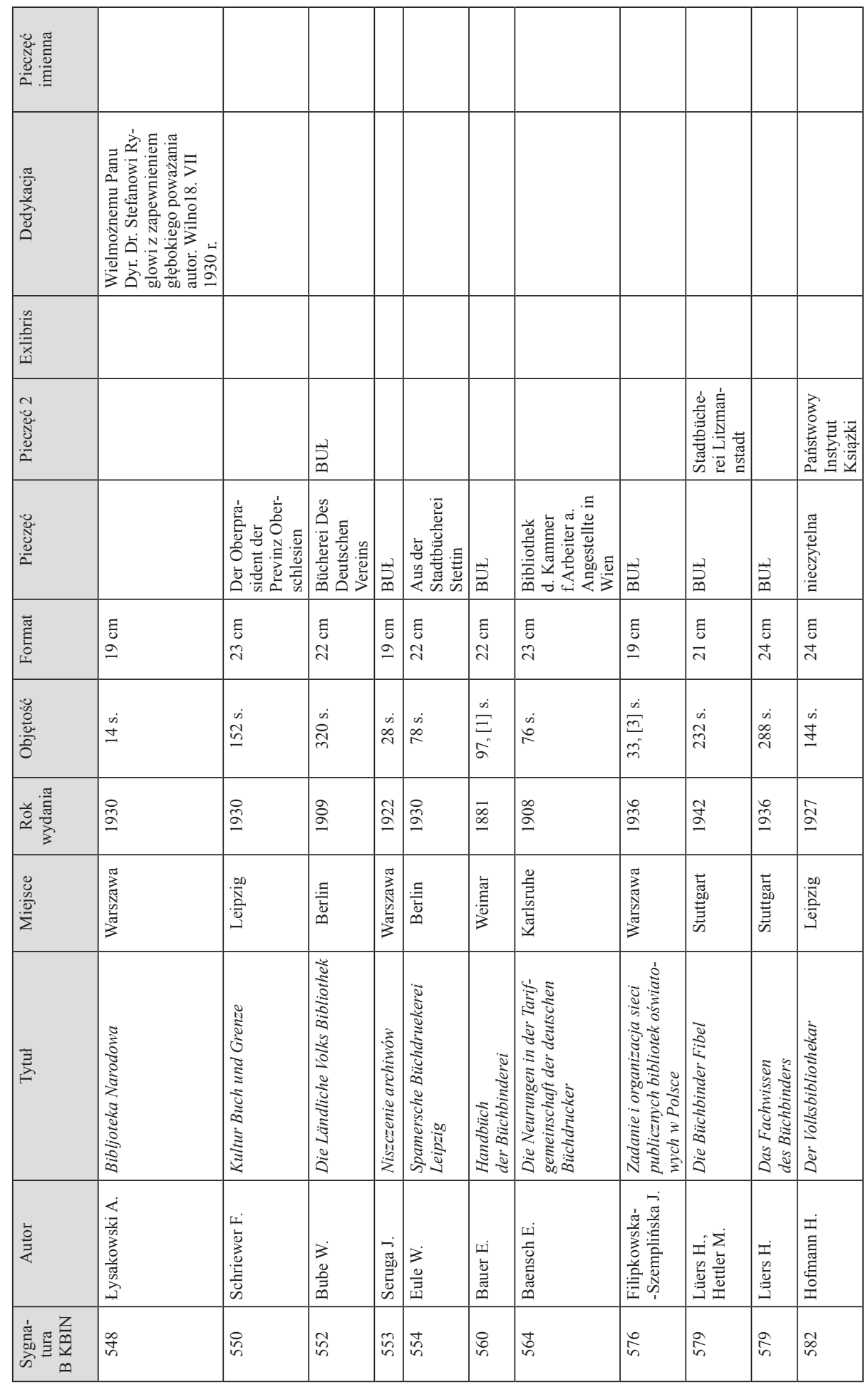




\begin{tabular}{|c|c|c|c|c|c|c|c|c|c|c|c|}
\hline 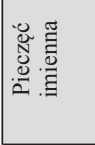 & & & & & & & & & 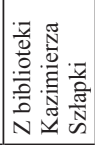 & & 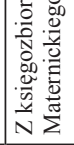 \\
\hline 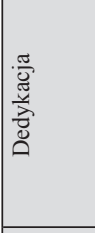 & & & & 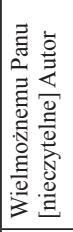 & & & & 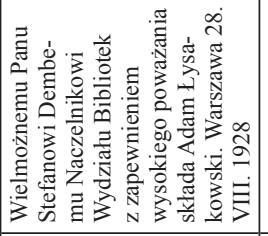 & & 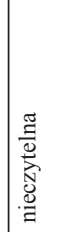 & \\
\hline 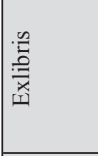 & & & 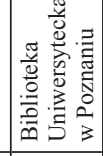 & & & 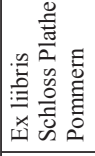 & & & & & \\
\hline 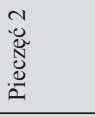 & & & & & & & & & & & \\
\hline 芯 & 岕 & 总 & 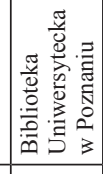 & & 岕 & & 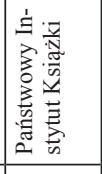 & & & & \\
\hline 誉 & $\begin{array}{l}\tilde{\Xi} \\
\stackrel{0}{\Xi}\end{array}$ & $\begin{array}{l}\Xi \\
\vdots \\
\varrho\end{array}$ & $\begin{array}{l}\Xi \\
\Xi \\
\varrho\end{array}$ & $\begin{array}{l}\vdots \\
\vdots \\
\text { a }\end{array}$ & $\begin{array}{l}\Xi \\
\vdots \\
\varrho\end{array}$ & \begin{tabular}{|l}
$\vdots$ \\
$\vdots$ \\
$\vdots$ \\
a
\end{tabular} & 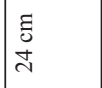 & $\begin{array}{l}\Xi \\
\vdots \\
\varrho\end{array}$ & $\begin{array}{l}\Xi \\
\vdots \\
\varrho\end{array}$ & $\begin{array}{l}\Xi \\
\vdots \\
n \\
n\end{array}$ & $\begin{array}{l}\tilde{z} \\
0 \\
\end{array}$ \\
\hline 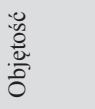 & $\begin{array}{l}\dot{\infty} \\
\pm \\
\pm\end{array}$ & $\dot{0}$ & 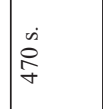 & in & $\dot{0}$ & & 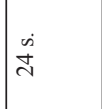 & $\stackrel{\dot{\infty}}{\Xi}$ & $\ddot{\Xi}$ & $\begin{array}{l}\dot{\dot{\Xi}} \\
\Xi \\
\dot{\infty}\end{array}$ & $\begin{array}{l}\dot{\infty} \\
\Xi \\
\infty \\
\infty\end{array}$ \\
\hline 兑璦 & & $\stackrel{2}{2}$ & 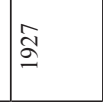 & 悉 & & בิ & 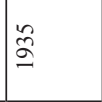 & $\stackrel{\infty}{2}$ & $\stackrel{\tilde{\infty}}{\stackrel{\infty}{\infty}}$ & $\stackrel{\cong}{\cong}$ & $\stackrel{\tilde{\infty}}{\infty}$ \\
\hline 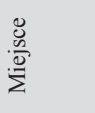 & & $\begin{array}{l}\frac{3}{5} \\
\frac{5}{0} \\
\frac{0}{3} \\
3\end{array}$ & 喜 & 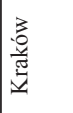 & & 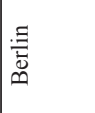 & 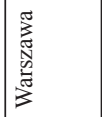 & $\frac{8}{3}$ & $\frac{8}{3}$ & 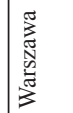 & 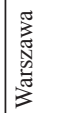 \\
\hline 惹 & 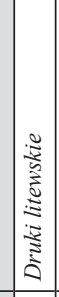 & 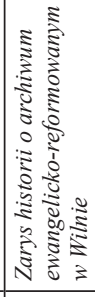 & 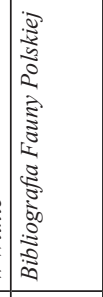 & 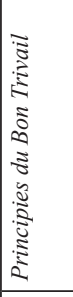 & 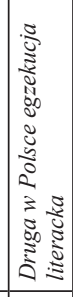 & 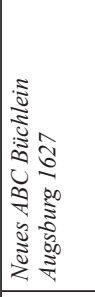 & 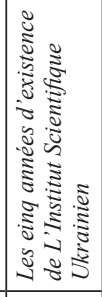 & 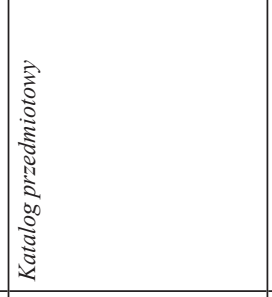 & 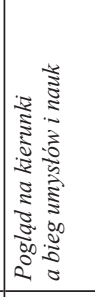 & 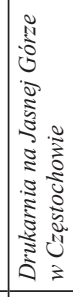 & 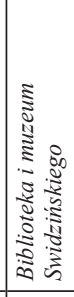 \\
\hline 曾 & & 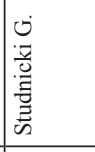 & & 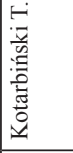 & 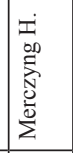 & 点 & & 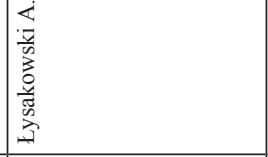 & 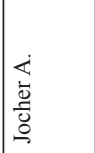 & & 吾 \\
\hline 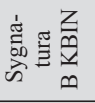 & 亏ू & ì & on & के & $\overrightarrow{8}$ & "๕̊ & : & $\frac{7}{6}$ & ఫ్రి & $\mathscr{\infty}$ & 度 \\
\hline
\end{tabular}




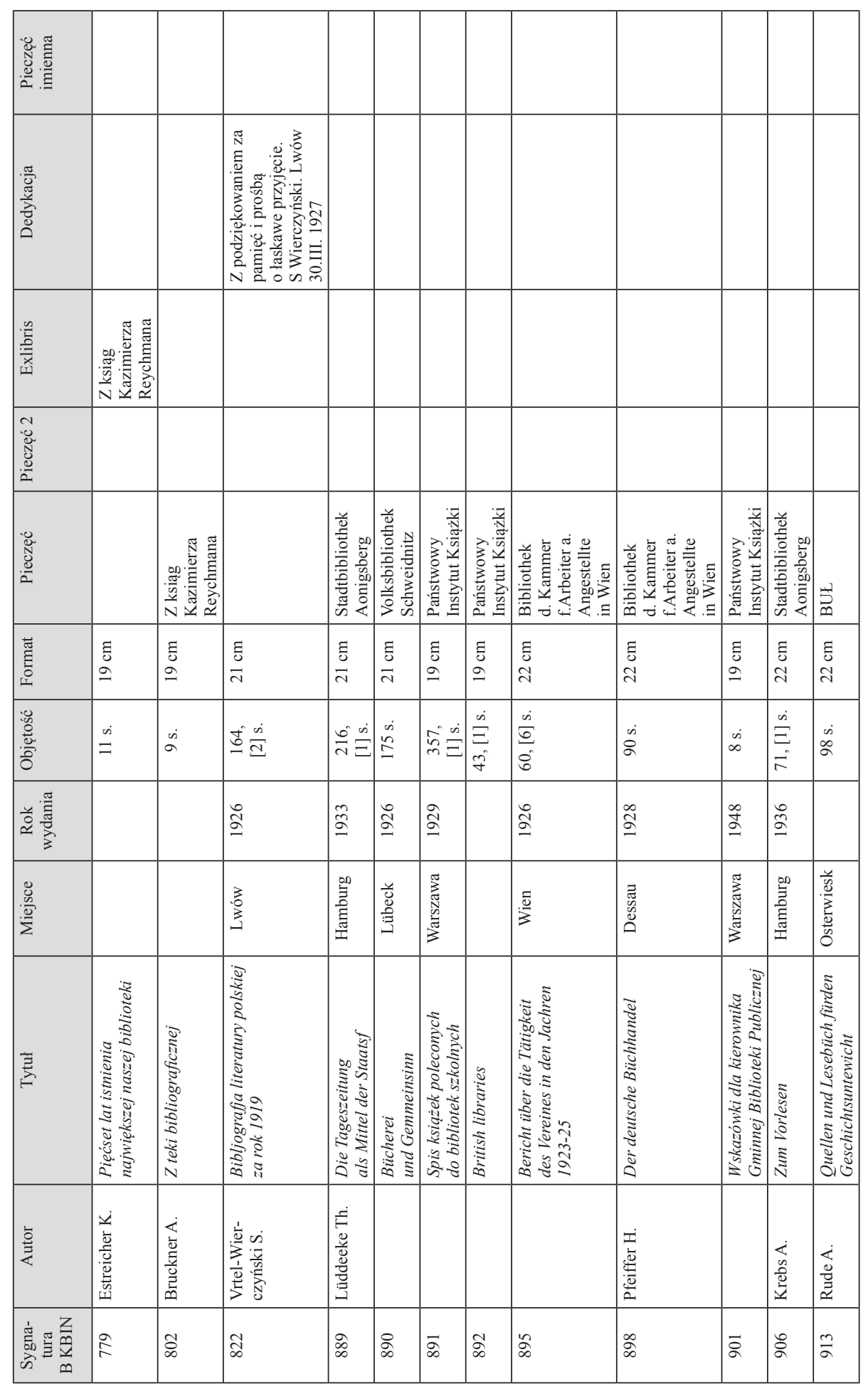




\begin{tabular}{|c|c|c|c|c|c|c|c|c|c|c|}
\hline 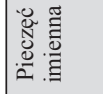 & & & & & & & & & & \\
\hline 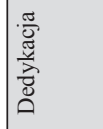 & & & & & & & & & & \\
\hline 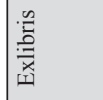 & & & & & & & & & & \\
\hline 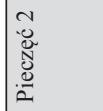 & & & & & & & & & & \\
\hline 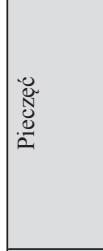 & 空 & 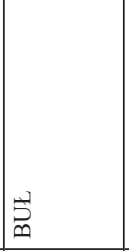 & 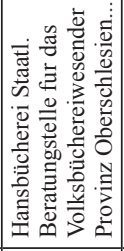 & 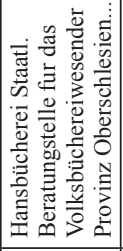 & 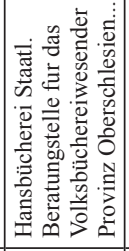 & 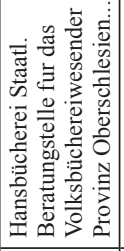 & 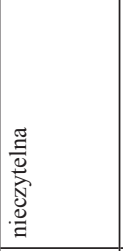 & 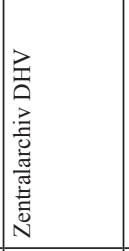 & 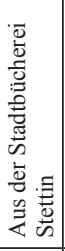 & 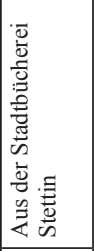 \\
\hline 芯 & 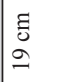 & $\frac{\tilde{\Xi}}{\vec{\sim}}$ & $\frac{\Xi}{\tilde{\nu}}$ & $\frac{\Xi}{\tilde{\sigma}}$ & $\frac{\Xi}{\tilde{\sigma}}$ & $\begin{array}{l}\tilde{\Xi} \\
\text { ते }\end{array}$ & $\frac{\tilde{J}}{\text { ते }}$ & $\frac{\Xi}{\tilde{\sigma}}$ & $\begin{array}{l}\frac{\Xi}{0} \\
\bar{\sim}\end{array}$ & $\frac{\Xi}{\tilde{0}}$ \\
\hline $\begin{array}{l}0 \\
0 \\
0 \\
0 \\
0 \\
0 \\
0\end{array}$ & $\begin{array}{l}\dot{m} \\
\Xi \\
n \\
n\end{array}$ & \begin{tabular}{|l}
$\dot{m}$ \\
$\tilde{N}$
\end{tabular} & $\dot{m}$ & $\stackrel{\dot{m}}{\Xi}$ & $\begin{array}{l}\dot{\infty} \\
\infty \\
\sim\end{array}$ & $\frac{\dot{m}}{m}$ & $\stackrel{\dot{m}}{\gtrless}$ & $\dot{\infty}$ & $\begin{array}{l}\dot{\infty} \\
\infty\end{array}$ & $\begin{array}{l}\dot{\infty} \\
\Xi \\
\dot{\Xi} \\
\infty\end{array}$ \\
\hline 尊 & $\hat{\check{\Omega}}$ & & $\vec{\sigma}$ & సे & $\overrightarrow{\widetilde{\Omega}}$ & $\widehat{\widehat{\Omega}}$ & $\stackrel{\vdots}{\varrho}$ & ڤ్ & $\stackrel{\curvearrowright}{\varrho}$ & $\underset{2}{2}$ \\
\hline 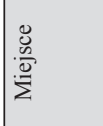 & 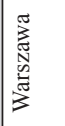 & & $\begin{array}{l}\text { on } \\
\text { 音 } \\
\text { ह్ } \\
\text { 壱 }\end{array}$ & $\begin{array}{l}\text { on } \\
\text { 吾 } \\
\text { E్ } \\
\text { 矛 }\end{array}$ & 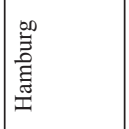 & 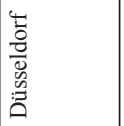 & $\mid$ & $\begin{array}{l}\text { on } \\
\text { 言 } \\
\text { 言 } \\
\text { 㷼 }\end{array}$ & 的 & 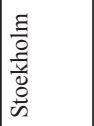 \\
\hline 总 & 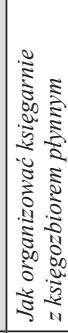 & 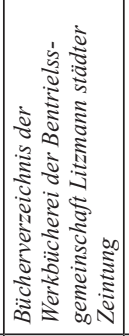 & 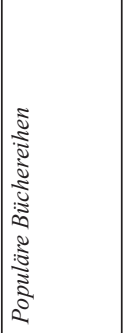 & 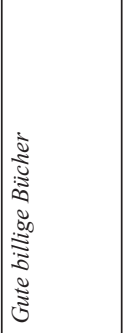 & 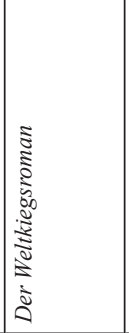 & 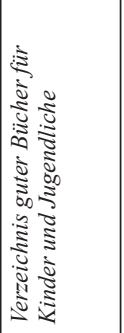 & 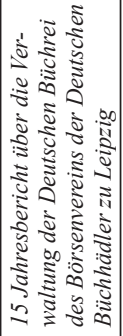 & 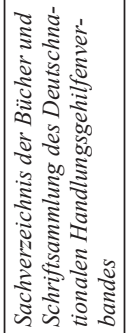 & 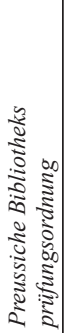 & 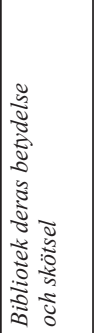 \\
\hline 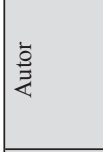 & 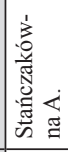 & & 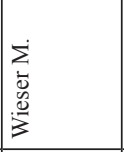 & & 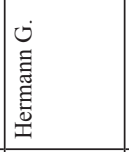 & & & & & 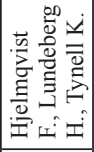 \\
\hline 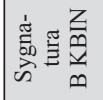 & $\frac{ \pm}{\sigma}$ & హ్ & $\overline{\widehat{\alpha}}$ & ลี & $\tilde{\Omega}$ & 志 & 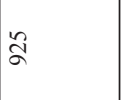 & హె & $\hat{\widehat{\alpha}}$ & $\stackrel{\infty}{\Omega}$ \\
\hline
\end{tabular}




\begin{tabular}{|c|c|c|c|c|c|c|c|c|c|c|}
\hline 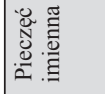 & & & & & & & & & & \\
\hline 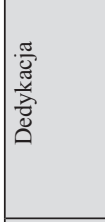 & & & & & & & & & & 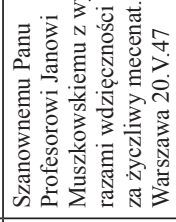 \\
\hline 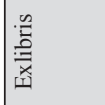 & & & & & & & & & & \\
\hline 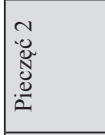 & & & & & & & & & 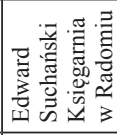 & \\
\hline 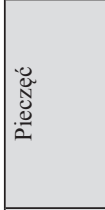 & 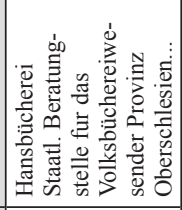 & 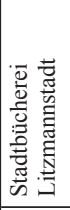 & 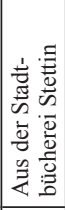 & 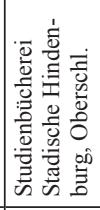 & 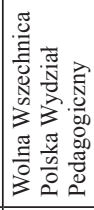 & S: & 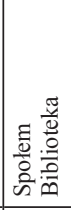 & 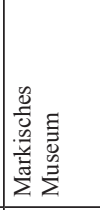 & 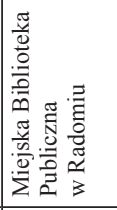 & \\
\hline 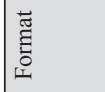 & $\frac{\Xi}{\bar{N}}$ & $\begin{array}{l}\Xi \\
\text { J } \\
\text { ปे }\end{array}$ & 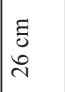 & 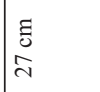 & 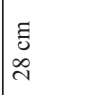 & $\begin{array}{l}\text { E } \\
\text { ते }\end{array}$ & 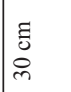 & $\mid \begin{array}{c}\tilde{E} \\
\infty \\
\text { ஸे }\end{array}$ & $\begin{array}{c}\tilde{E} \\
\infty \\
\infty\end{array}$ & 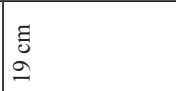 \\
\hline 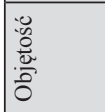 & $\stackrel{\dot{m}}{=}$ & $\begin{array}{l}\dot{m} \\
\dot{f} \\
\dot{m}\end{array}$ & & $\dot{\dot{n}}$ & $\begin{array}{l}\dot{D} \\
\dot{0} \\
\infty\end{array}$ & & \begin{tabular}{|l|}
$\dot{\dot{a}}$ \\
$\Xi$ \\
$\dot{q}$
\end{tabular} & 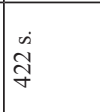 & $\begin{array}{l}\dot{s} \\
\dot{0}\end{array}$ & \begin{tabular}{|l|}
$\dot{x}$ \\
0 \\
$\infty$ \\
$\infty$ \\
$\infty$
\end{tabular} \\
\hline 蓆 & 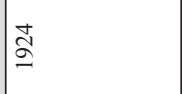 & $\stackrel{\Xi}{\Omega}$ & $\frac{\sqrt{\infty}}{\underline{-}}$ & $\frac{n}{2}$ & $\overrightarrow{2}$ & $\bar{\sigma}$ & & $\stackrel{ \pm}{2}$ & 竎 & 孚 \\
\hline 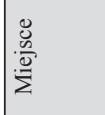 & 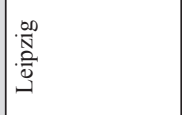 & $\mid \frac{.0}{\mathrm{~N}}$ & 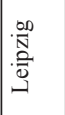 & 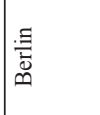 & $\mid$ & 咅 & & 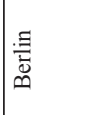 & 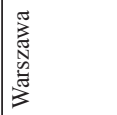 & 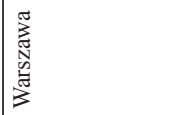 \\
\hline 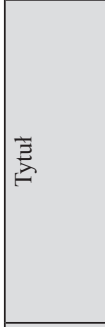 & 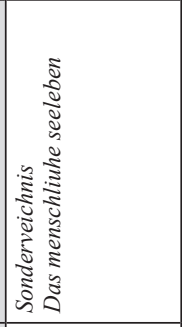 & 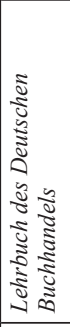 & 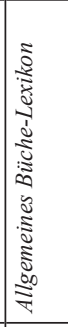 & 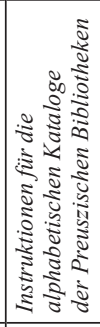 & 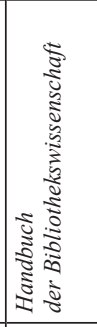 & 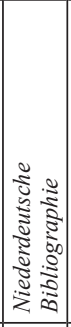 & 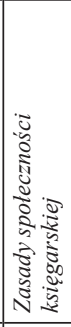 & 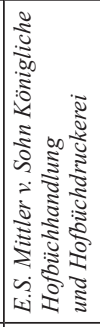 & 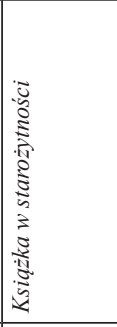 & 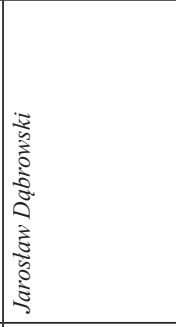 \\
\hline 芠 & & 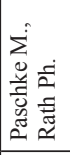 & 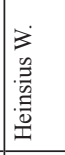 & & & 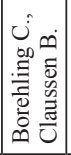 & 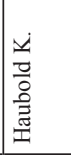 & & 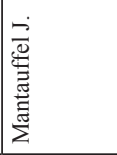 & 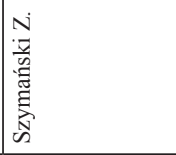 \\
\hline 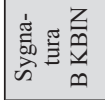 & స్ & 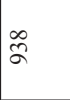 & 영 & 番 & 芯 & $\tilde{n}$ & $\stackrel{\infty}{2}$ & रूे & $\stackrel{+}{\stackrel{9}{\sigma}}$ & $\stackrel{n}{\varrho}$ \\
\hline
\end{tabular}




\begin{tabular}{|c|c|c|c|c|c|c|c|c|c|c|c|c|}
\hline 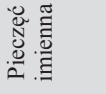 & & & & & & & & & & & & \\
\hline 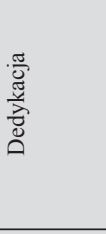 & & & & & & & 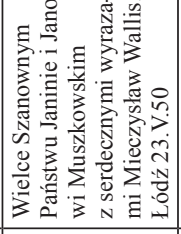 & & & & & \\
\hline 望 & & & & & & & & & & & & \\
\hline 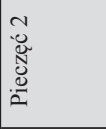 & & & & & & & & 焉 & & 空 & & \\
\hline 若 & 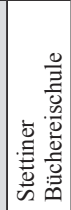 & 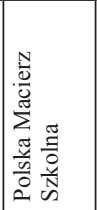 & 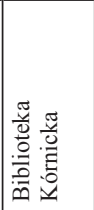 & 禽 & 㟔 & 夏 & & 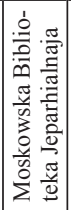 & 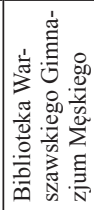 & 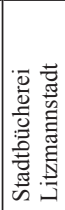 & 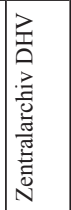 & 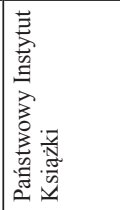 \\
\hline 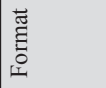 & हี & $\begin{array}{l}\tilde{\Xi} \\
\infty \\
\underline{-}\end{array}$ & 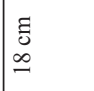 & $\begin{array}{c}\text { ב } \\
\text { ป } \\
\text { ป }\end{array}$ & $\begin{array}{l}\text { ह } \\
\text { ป } \\
\text { ป }\end{array}$ & हี & हี & 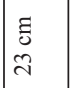 & $\begin{array}{l}\Xi \\
\tilde{0} \\
\text { ते }\end{array}$ & 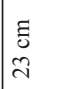 & $\begin{array}{l}\text { ร } \\
\text { ปิ }\end{array}$ & ह \\
\hline 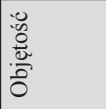 & $\dot{\dot{n}}$ & $\begin{array}{l}\dot{x} \\
\mathcal{F}\end{array}$ & $\dot{q} \frac{\dot{m}}{\dot{m}}$ & $\begin{array}{l}\dot{\infty} \\
\infty \\
\infty \\
\infty\end{array}$ & $\begin{array}{l}\dot{1} \\
\dot{0} \\
\ddot{n}\end{array}$ & \begin{tabular}{|l|}
$\dot{m}$ \\
$\Xi$ \\
$\dot{\infty}$
\end{tabular} & $\begin{array}{l}\dot{\infty} \\
\propto \\
\infty\end{array}$ & $\begin{array}{l}\dot{1} \\
\dot{0} \\
\approx\end{array}$ & & $\begin{array}{l}\dot{n} \\
\dot{a} \\
\dot{q}\end{array}$ & $\dot{m}$ & \\
\hline 苑 & $\stackrel{2}{2}$ & 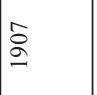 & $\frac{m}{9}$ & $\underset{\substack{1 \\
\infty \\
\infty}}{0}$ & $\begin{array}{l}+ \\
\infty \\
\infty \\
\infty\end{array}$ & $\stackrel{\infty}{\Omega}$ & gे & $\begin{array}{l}\mathscr{0} \\
\infty \\
1\end{array}$ & $\stackrel{\infty}{\circ}$ & 웅 & $\stackrel{0}{\infty}$ & f \\
\hline 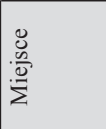 & 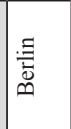 & 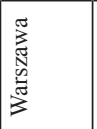 & 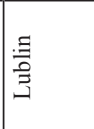 & 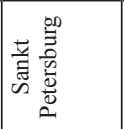 & 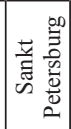 & - & 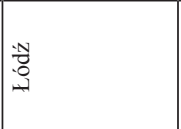 & 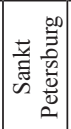 & 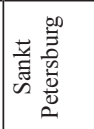 & 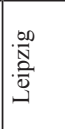 & 竞 & 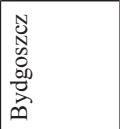 \\
\hline 跑 & 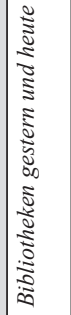 & 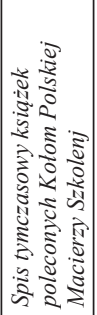 & 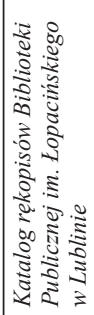 & 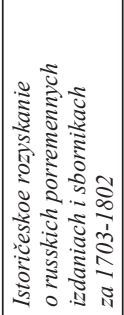 & 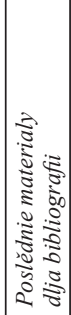 & 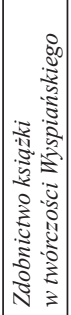 & 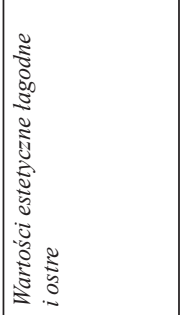 & 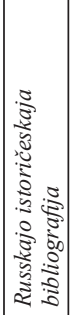 & 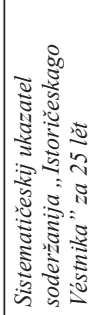 & 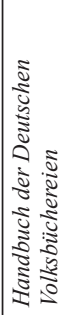 & 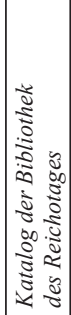 & 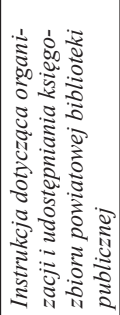 \\
\hline 尝 & 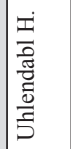 & & 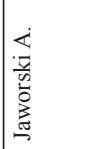 & 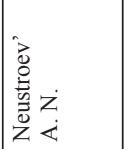 & 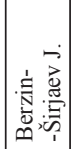 & 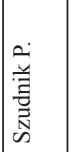 & 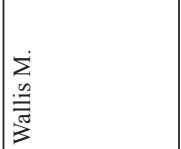 & & 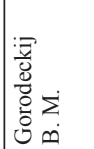 & & & \\
\hline 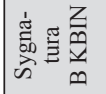 & $\overrightarrow{\widehat{\Xi}}$ & $\vec{f}$ & 就 & $\bar{\Xi}$ & : & 。ㅇ & ? & 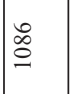 & $\stackrel{\mathscr{o}}{\stackrel{\infty}{0}}$ & $\stackrel{\partial}{\stackrel{\circ}{\varrho}}$ & 吉 & $\stackrel{\infty}{\cong}$ \\
\hline
\end{tabular}




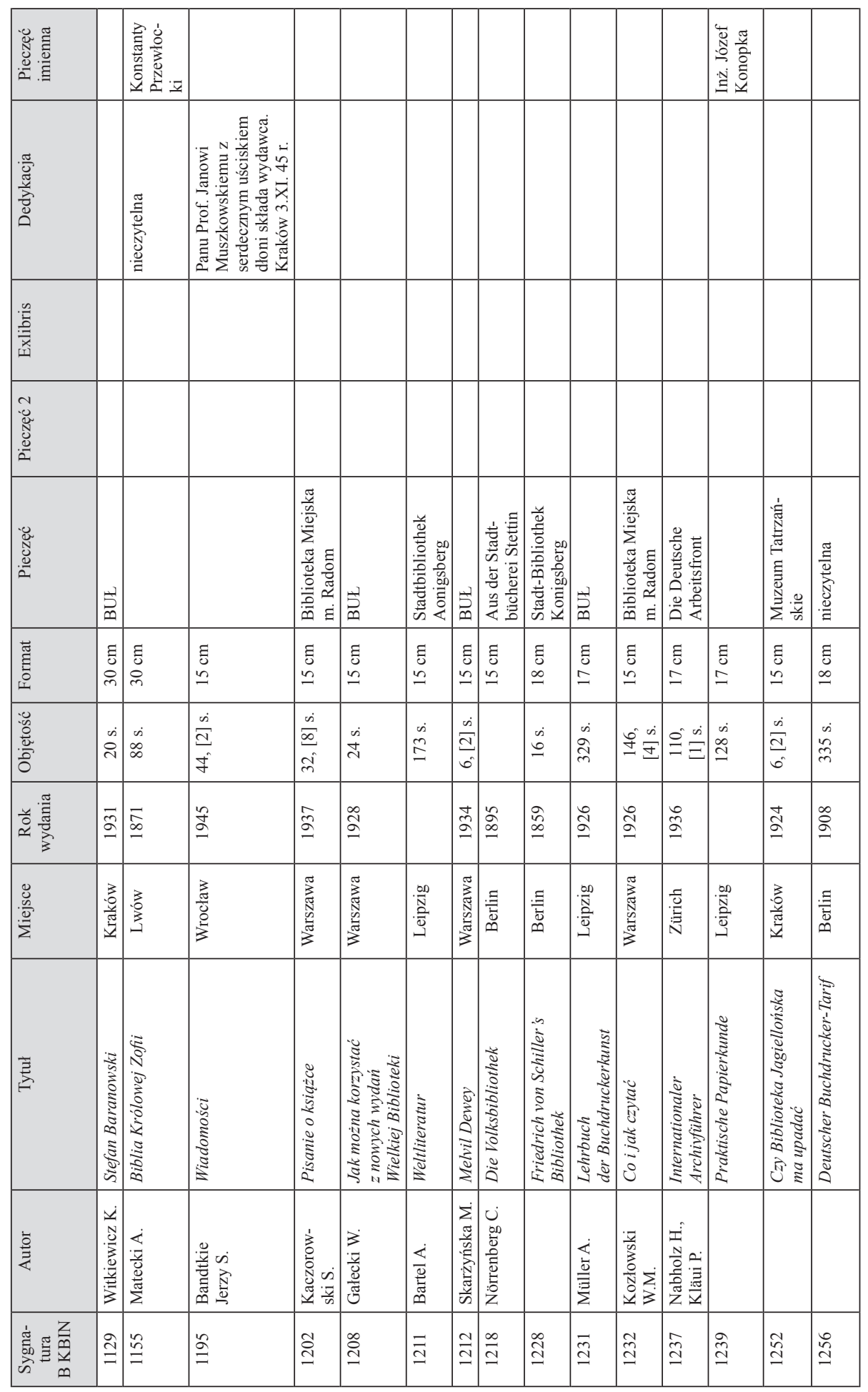




\begin{tabular}{|c|c|c|c|c|c|c|c|c|c|c|c|}
\hline 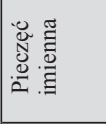 & 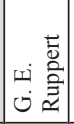 & & & & 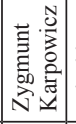 & 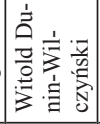 & 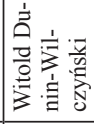 & & & & \\
\hline 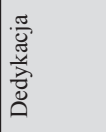 & & & & & & & & & & & \\
\hline 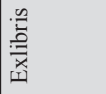 & & & & & & & & & & & \\
\hline 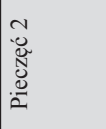 & & & & & & & & & & 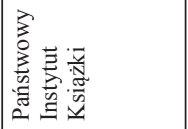 & \\
\hline 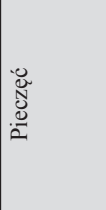 & & 岎 & 岎 & 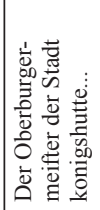 & & & & 㟔 & 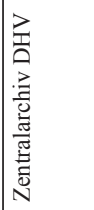 & 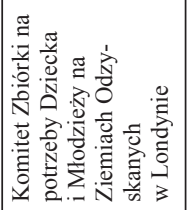 & 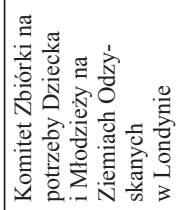 \\
\hline 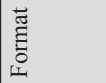 & \begin{tabular}{|l}
$\tilde{\Xi}$ \\
$\infty$ \\
-
\end{tabular} & 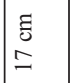 & 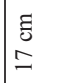 & $\begin{array}{l}\Xi \\
\Xi \\
\beth\end{array}$ & $\begin{array}{l}\tilde{\Xi} \\
0 \\
0\end{array}$ & $\begin{array}{l}\tilde{\Xi} \\
0 \\
0\end{array}$ & $\begin{array}{c}\tilde{\Xi} \\
\vdots \\
0\end{array}$ & 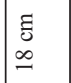 & $\begin{array}{l}\tilde{\Xi} \\
\infty \\
-\infty\end{array}$ & $\begin{array}{c}\tilde{z} \\
\text { zo } \\
0\end{array}$ & $\begin{array}{l}\tilde{\Xi} \\
\vdots \\
0\end{array}$ \\
\hline 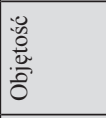 & $\begin{array}{c}\dot{m} \\
\tilde{m} \\
m\end{array}$ & 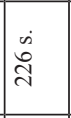 & $\begin{array}{l}\dot{n} \\
\grave{\Xi}\end{array}$ & $\begin{array}{l}\dot{x} \\
\hat{0} \\
\tilde{N}\end{array}$ & $\begin{array}{l}\dot{m} \\
\dot{n}\end{array}$ & \begin{tabular}{|l}
$\dot{n}$ \\
$\dot{\sigma}$ \\
$\dot{i}$ \\
\end{tabular} & $\begin{array}{l}\dot{\infty} \\
\stackrel{5}{5} \\
\dot{\infty}\end{array}$ & $\begin{array}{l}\dot{D} \\
\dot{J}\end{array}$ & $\begin{array}{l}\dot{m} \\
\dot{d} \\
\dot{n}\end{array}$ & $\begin{array}{l}\dot{\phi} \\
\stackrel{2}{\alpha}\end{array}$ & $\begin{array}{l}\dot{m} \\
\tilde{n} \\
\tilde{n} \\
\end{array}$ \\
\hline 尊 & $\widehat{\widehat{\Omega}}$ & $\stackrel{g}{g}$ & $\frac{0}{9}$ & $\exists$ & $\stackrel{\infty}{\stackrel{2}{2}}$ & $\stackrel{0}{2}$ & $\stackrel{\check{2}}{\approx}$ & $\underset{\Omega}{2}$ & $\stackrel{\stackrel{2}{2}}{2}$ & 告 & $\stackrel{\infty}{2}$ \\
\hline $\begin{array}{l}\mathscr{8} \\
\frac{\mathscr{m}}{2} \\
\stackrel{2}{\Sigma}\end{array}$ & 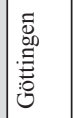 & $\begin{array}{l}.00 \\
\frac{.00}{10} \\
\frac{0}{0} \\
-1\end{array}$ & $\begin{array}{l}.00 \\
\stackrel{.00}{0} \\
\stackrel{0}{0} \\
-1\end{array}$ & 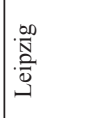 & 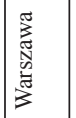 & 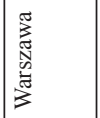 & 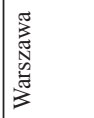 & $\begin{array}{l}.00 \\
\frac{.00}{1} \\
\frac{0}{0} \\
-1\end{array}$ & 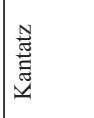 & $\begin{array}{l}\text { E } \\
\text { 吾 } \\
0 \\
-3\end{array}$ & $\begin{array}{l}\text { E } \\
\text { 总 } \\
\text { 苟 } \\
\end{array}$ \\
\hline 总 & 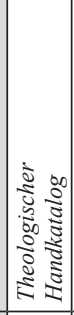 & 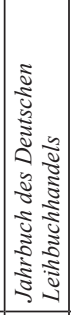 & 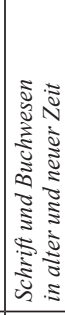 & 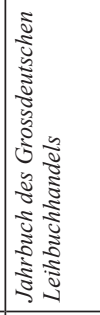 & 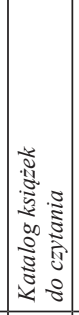 & 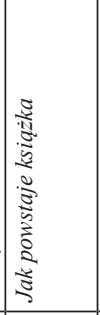 & 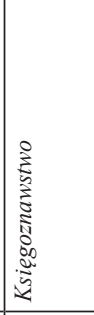 & 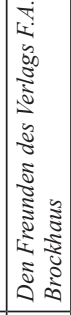 & 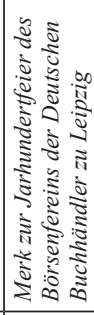 & 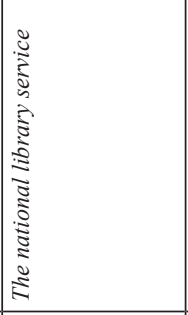 & 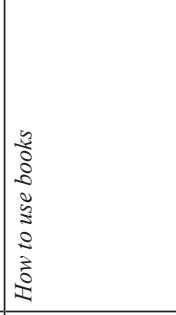 \\
\hline 总 & & & 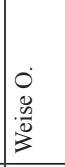 & & & 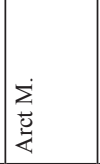 & 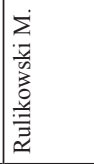 & & & 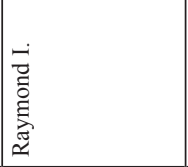 & 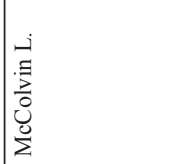 \\
\hline 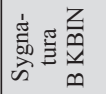 & $\stackrel{\infty}{\mathfrak{g}}$ & \begin{tabular}{l} 
: \\
\hdashline
\end{tabular} & 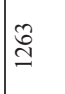 & $\stackrel{\overbrace{}}{\cong}$ & $\mid \begin{array}{l}\infty \\
\stackrel{\infty}{\simeq}\end{array}$ & 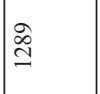 & 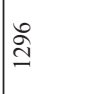 & 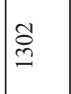 & 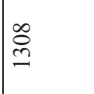 & $\stackrel{\circ}{m}$ & $\underset{m}{\bar{m}}$ \\
\hline
\end{tabular}




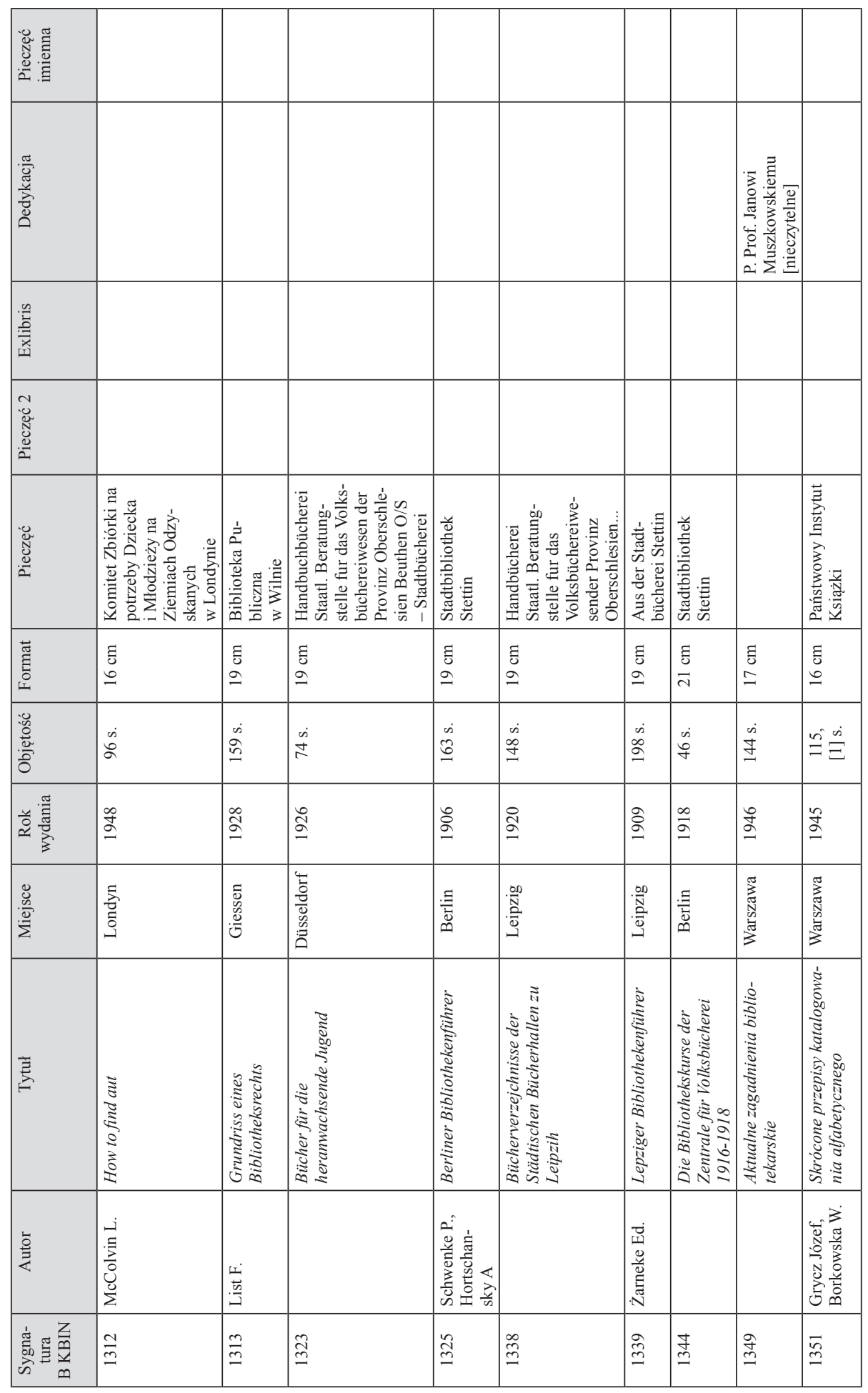




\begin{tabular}{|c|c|c|c|c|c|c|c|c|c|c|c|c|}
\hline 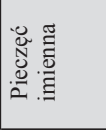 & & 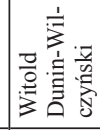 & 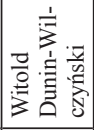 & & & & & & & & & \\
\hline 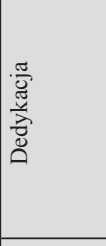 & & & & 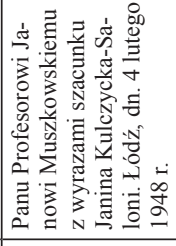 & & & & & & & & \\
\hline 啇 & & & & & & & & & & & & \\
\hline 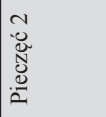 & & & & & & & & & & & & \\
\hline 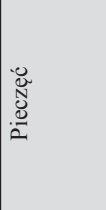 & 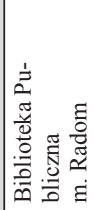 & & & & 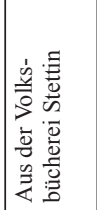 & 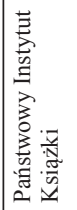 & 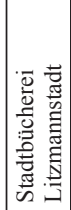 & 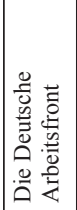 & 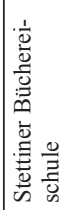 & 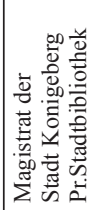 & 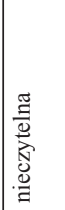 & 容 \\
\hline 莺 & \begin{tabular}{|l}
$\tilde{0}$ \\
0 \\
0
\end{tabular} & 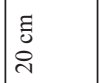 & 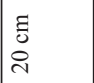 & $\begin{array}{l}\tilde{\Xi} \\
\vdots \\
0\end{array}$ & $\frac{\tilde{\Xi}}{\overline{\mathrm{N}}}$ & $\begin{array}{l}\tilde{\Xi} \\
\vdots \\
0 \\
0\end{array}$ & $\frac{\tilde{\Xi}}{\vec{N}}$ & $\frac{\tilde{\Xi}}{\vec{N}}$ & 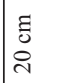 & $\frac{\tilde{\Xi}}{\vec{N}}$ & $\begin{array}{l}\tilde{\Xi} \\
\bar{\sim}\end{array}$ & $\begin{array}{l}\tilde{E} \\
\tilde{\Xi} \\
\varrho\end{array}$ \\
\hline 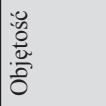 & $\underbrace{\infty}_{\tilde{\Xi}}$ & $\begin{array}{l}\dot{m} \\
\dot{\widehat{े}}\end{array}$ & $\begin{array}{l}\dot{1} \\
0 \\
\dot{m}\end{array}$ & $\begin{array}{l}\dot{m} \\
\dot{m}\end{array}$ & $\begin{array}{l}\frac{\dot{m}}{m} \\
\dot{m} \\
\dot{n}\end{array}$ & \begin{tabular}{|l}
$\dot{m}$ \\
$\tilde{N}$ \\
$\tilde{N}$
\end{tabular} & $\dot{m}$ & $\dot{m}$ & $\stackrel{\dot{m}}{\exists}$ & & $\stackrel{\dot{m}}{\stackrel{\Delta}{\Xi}}$ & $\stackrel{\dot{m}}{\stackrel{N}{N}}$ \\
\hline 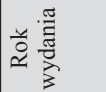 & $\stackrel{+}{\varrho}$ & $\overrightarrow{\widehat{\Omega}}$ & $\underset{\Omega}{\mathscr{2}}$ & f & 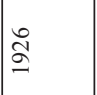 & 年 & I & $\stackrel{\infty}{\stackrel{\infty}{\Omega}}$ & $\underset{\Omega}{\Omega}$ & $\vec{\Omega}$ & & $\frac{2}{2}$ \\
\hline 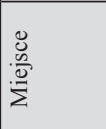 & 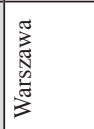 & 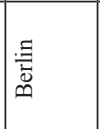 & 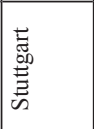 & 资 & 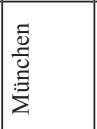 & 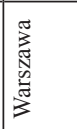 & $\begin{array}{l}.00 \\
\frac{.00}{10} \\
\frac{2}{3} \\
-1\end{array}$ & 穿 & 咅 & 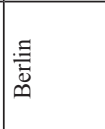 & 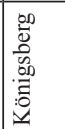 & 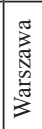 \\
\hline$\sum_{k}^{E}$ & 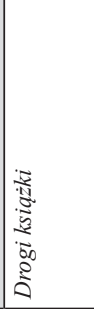 & 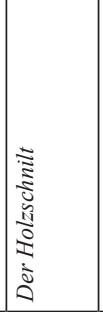 & 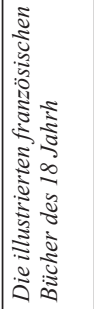 & 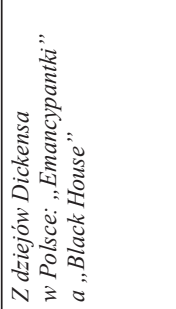 & 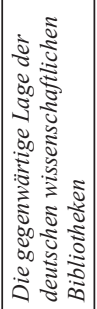 & 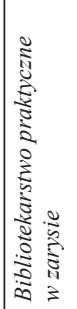 & 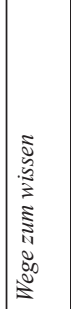 & 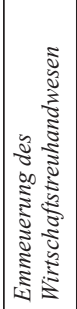 & 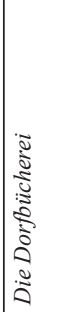 & 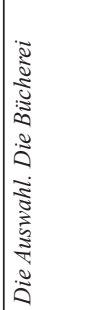 & 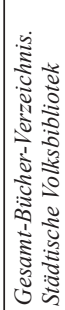 & 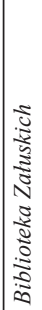 \\
\hline 旁 & 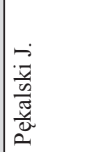 & 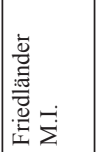 & 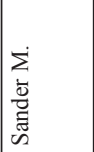 & 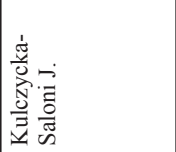 & 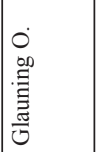 & 通 & 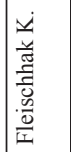 & & 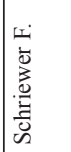 & & & 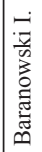 \\
\hline 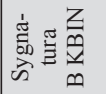 & $\begin{array}{l}\overrightarrow{0} \\
\text { - }\end{array}$ & $\begin{array}{l}\widetilde{J} \\
\text { లn }\end{array}$ & 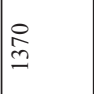 & 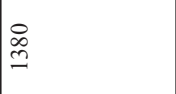 & 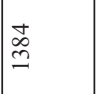 & $\mid \begin{array}{l}\infty \\
\infty \\
\end{array}$ & 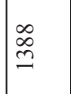 & 䟱 & 享 & 高 & $\stackrel{\circ}{\underset{\exists}{\Xi}}$ & $\underset{\exists}{\stackrel{\partial}{\Xi}}$ \\
\hline
\end{tabular}




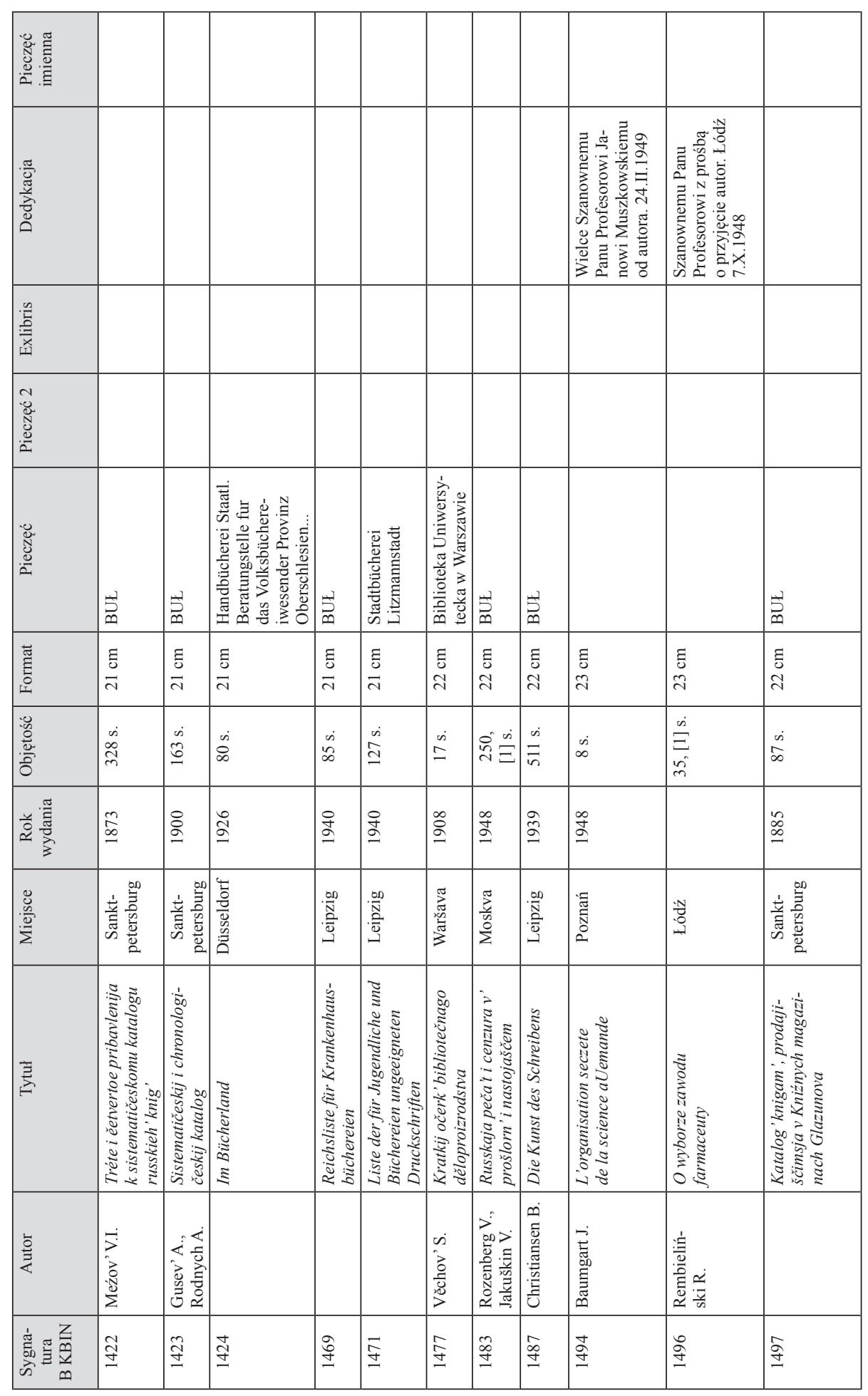




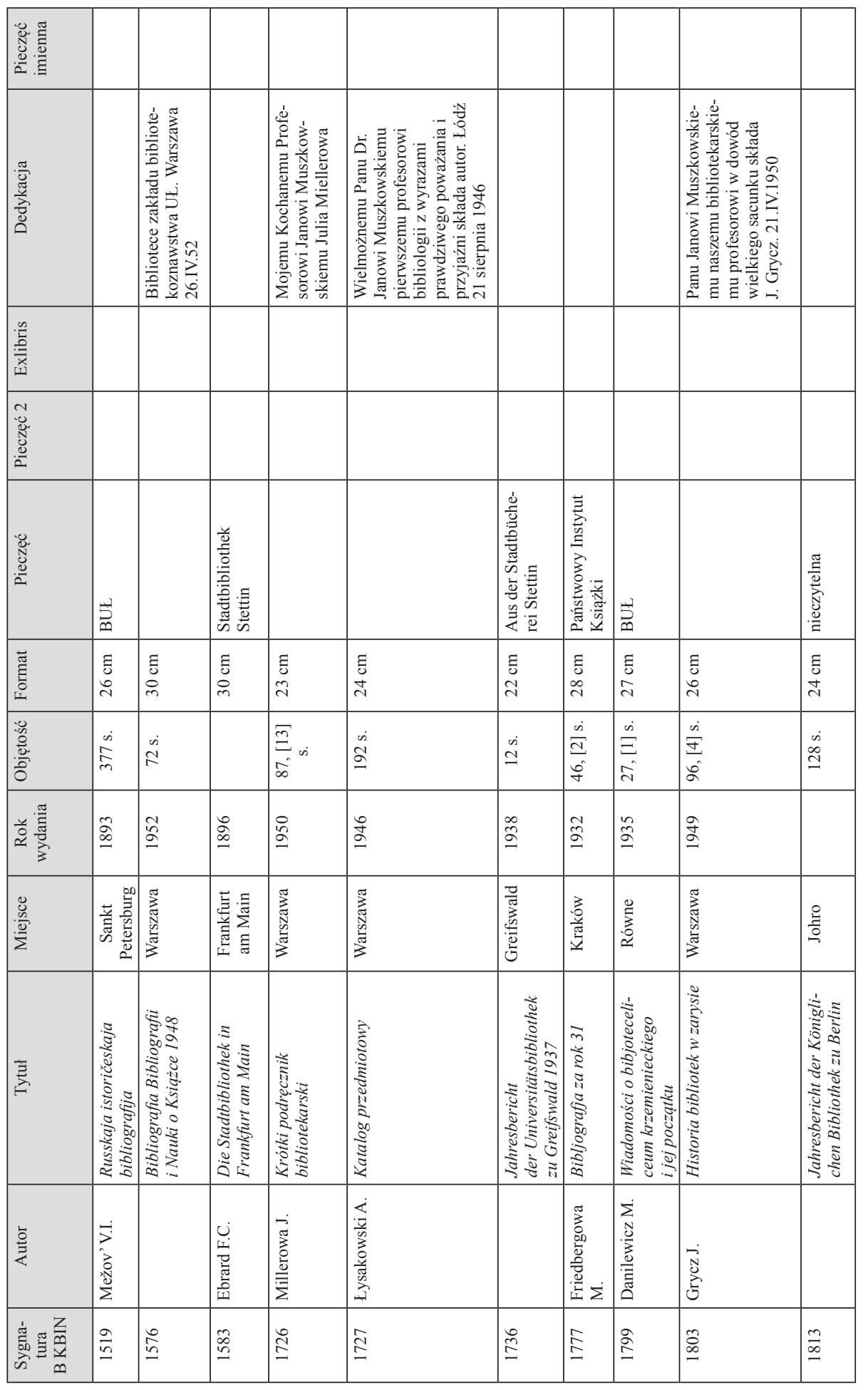




\begin{tabular}{|c|c|c|c|c|c|c|c|c|c|c|c|c|}
\hline 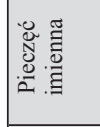 & & & 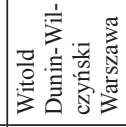 & & & & & & & & & \\
\hline $\begin{array}{l}\frac{\pi}{\widetilde{\pi}} \\
\frac{\pi}{4} \\
\frac{0}{0} \\
0\end{array}$ & & & & & & & & 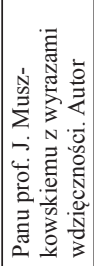 & 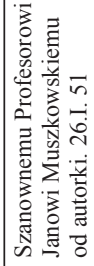 & 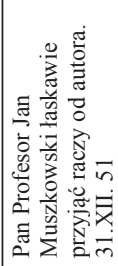 & 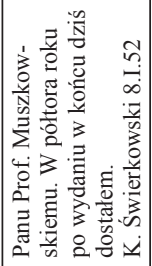 & \\
\hline 象 & & & & & & & & & & & & \\
\hline 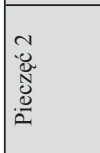 & 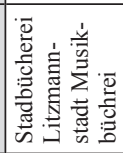 & & & & & & & & & & & \\
\hline 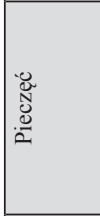 & 岕 & 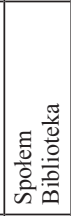 & & 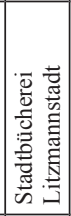 & & 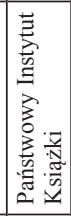 & 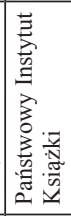 & & & & & 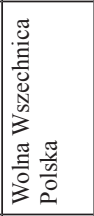 \\
\hline 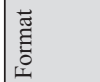 & 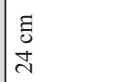 & $\mid \begin{array}{l}\tilde{\Xi} \\
\text { ह } \\
0\end{array}$ & 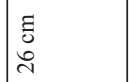 & 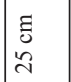 & $\mid \begin{array}{c}\tilde{c} \\
\infty \\
\infty \\
\sim\end{array}$ & 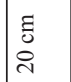 & 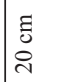 & 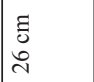 & 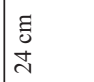 & 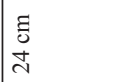 & 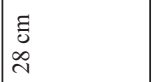 & 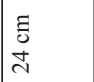 \\
\hline 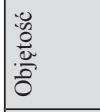 & $\begin{array}{l}\dot{m} \\
\dot{q} \\
\dot{m}\end{array}$ & \begin{tabular}{|l}
$\dot{m}$ \\
$\Xi$ \\
$\dot{\sigma}$
\end{tabular} & $\begin{array}{l}\dot{\infty} \\
\Xi \\
\dot{\infty} \\
\dot{\infty}\end{array}$ & $\begin{array}{l}\dot{\infty} \\
\infty \\
\infty \\
m\end{array}$ & \begin{tabular}{|l|}
$\dot{x}$ \\
$\dot{q}$ \\
\end{tabular} & $\begin{array}{l}\dot{n} \\
\stackrel{d}{\Omega}\end{array}$ & $\begin{array}{l}\dot{\infty} \\
\tilde{\Omega} \\
\Omega\end{array}$ & $\begin{array}{l}\dot{m} \\
\Xi \\
\dot{m}\end{array}$ & $\begin{array}{l}\dot{m} \\
\dot{d}\end{array}$ & $\dot{\infty}$ & $\dot{\infty}$ & \begin{tabular}{|l}
$\dot{0}$ \\
$\tilde{c}$ \\
$\tilde{n}$
\end{tabular} \\
\hline 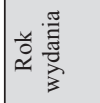 & $\stackrel{\curvearrowright}{\Omega}$ & & $\underset{\sim}{\approx}$ & 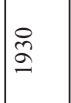 & $\stackrel{f}{g}$ & $\stackrel{\circ}{2}$ & 过 & $\overrightarrow{\widetilde{n}}$ & $\vec{\sigma}$ & $\stackrel{\circ}{2}$ & $\stackrel{\circ}{2}$ & \\
\hline 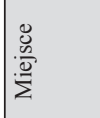 & 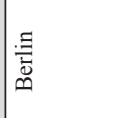 & & 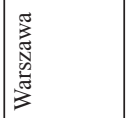 & 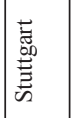 & 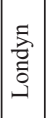 & 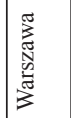 & 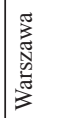 & 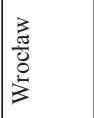 & 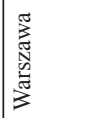 & & \begin{tabular}{|l}
3 \\
$\frac{3}{0}$ \\
0 \\
0 \\
3
\end{tabular} & \\
\hline 胥 & 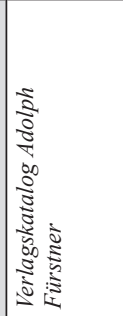 & 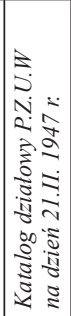 & 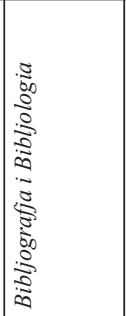 & 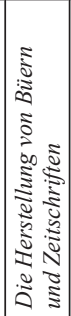 & 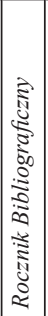 & 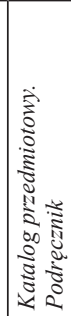 & 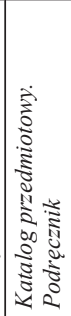 & 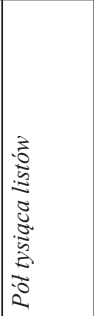 & 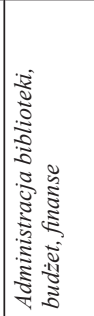 & 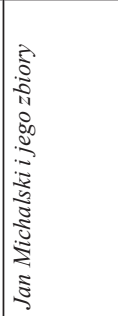 & 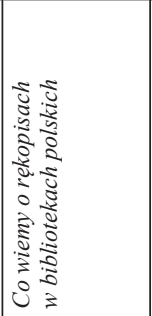 & 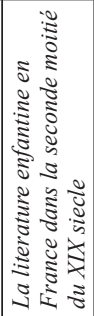 \\
\hline 䓂 & & & 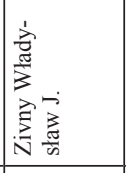 & 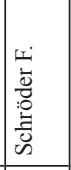 & 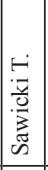 & 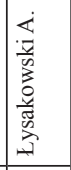 & 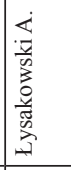 & 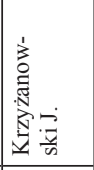 & 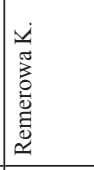 & 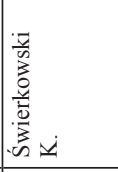 & 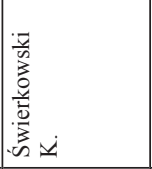 & 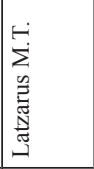 \\
\hline 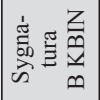 & 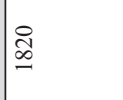 & $\begin{array}{l}\infty \\
\infty \\
\infty\end{array}$ & $\begin{array}{l}\infty \\
\infty \\
\infty\end{array}$ & $\overrightarrow{\widehat{D}}$ & $\begin{array}{l} \pm \\
\infty \\
\infty\end{array}$ & ఏ & ఏ & ֶू & $\stackrel{\circ}{\circ}$ & d & $\stackrel{2}{2}$ & $\overrightarrow{\stackrel{్}{े}}$ \\
\hline
\end{tabular}

